
COMMERCE

National QC au 100 of $45753^{d s}$ no.764 1973 c. 2 
The National Bureau of Standards ${ }^{1}$ was established by an act of Congress March 3, 1901. The Bureau's overall goal is to strengthen and advance the Nation's science and technology and facilitate their effective application for public benefit. To this end, the Bureau conducts research and provides: (1) a basis for the Nation's physical measurement system, (2) scientific and technological services for industry and government, (3) a technical basis for equity in trade, and (4) technical services to promote public safety. The Bureau consists of the Institute for Basic Standards, the Institute for Materials Research, the Institute for Applied Technology, the Center for Computer Sciences and Technology, and the Office for Information Programs.

THE INSTITUTE FOR BASIC STANDARDS provides the central basis within the United States of a complete and consistent system of physical measurement; coordinates that system with measurement systems of other nations; and furnishes essential services leading to accurate and uniform physical measurements throughout the Nation's scientific community, industry, and commerce. The Institute consists of a Center for Radiation Research, an Office of Measurement Services and the following divisions:

Applied Mathematics - Electricity - Mechanics - Heat - Optical Physics Linac Radiation" - Nuclear Radiation " ... Applied Radiation " - Quantum Electronics : - Electromagnetics : - Time and Frequency " - Laboratory Astrophysics : - Cryogenics:.

THE INSTITUTE FOR MATERIALS RESEARCH conducts materials research leading to improved methods of measurement, standards, and data on the properties of well-characterized materials needed by industry, commerce, educational institutions, and Government; provides advisory and research services to other Government agencies; and develops, produces, and distributes standard reference materials. The Institute consists of the Office of Standard Reference Materials and the following divisions:

Analytical Chemistry-Polymers-Metallurgy-Inorganic Materials-Reactor Radiation-Physical Chemistry.

THE INSTITUTE FOR APPLIED TECHNOLOGY provides technical services to promote the use of available technology and to facilitate technological innovation in industry and Government; cooperates with public and private organizations leading to the development of technological standards (including mandatory safety standards), codes and methods of test; and provides technical advice and services to Government agencies upon request. The Institute also monitors NBS engineering standards activities and provides liaison between NBS and national and international engineering standards bodies. The Institute consists of a Center for Building Technology and the following divisions and offices:

Engineering and Product Standards-Weights and Measures-Invention and Innovation-Product Evaluation Technology-Electronic Technology-Technical Analysis-Measurement Engineering-Building Standards and Code Seryices ${ }^{4}$ - Housing Technology ${ }^{4}$-Federal Building Technology $y^{4}$-Structures, Materials and Life Safety ${ }^{4}$-Building Environment ${ }^{*}$-Technical Evaluation and Application ${ }^{4}$-Fire Technology.

THE INSTITUTE FOR COMPUTER SCIENCES AND TECHNOLOGY conducts research and provides technical services designed to aid Government agencies in improving cost effectiveness in the conduct of their programs through the selection, acquisition, and effective utilization of automatic data processing equipment; and serves as the principal focus within the executive branch for the development of Federal standards for automatic data processing equipment, techniques, and computer languages. The Center consists of the following offices and divisions:

Information Processing Standards-Computer Information-Computer Services -Systems Development-Information Processing Technology.

THE OFFICE FOR INFORMATION PROGRAMS promotes optimum dissemination and accessibility of scientific information generated within NBS and other agencies of the Federal Government; promotes the development of the National Standard Reference Data System and a system of information analysis centers dealing with the broader aspects of the National Measurement System; provides appropriate services to ensure that the NBS staff has optimum accessibility to the scientific information of the world, and directs the public information activities of the Bureau. The Office consists of the following organizational units:

Office of Standard Reference Data-Office of Technical Information and Publications-Library-Office of International Relations.

\footnotetext{
1 Headquarters and Laboratories at Gaithersburg, Maryland, unless otherwise noted; malling address Washington, D.C. 20234

Part of the Center for Radiation Resenrch.

Located at Boulder, Colorado $5030^{2}$.

- Part of the Center for Bullding T'echnolog.
} 


\section{An Investigation of the Stability of and Insulation Leakage in Some High Temperature Resistance Thermometers: An Interim Report}

Sharrill D. Wood

Heat Division

Institute for Basic Standards

National Bureau of Standards

Washington, D.C. 20234

NBS Technical Notes are designed to supplement the Bureau's regular publications program. They provide a means for making available scientific data that are of transient or limited interest. Technical Notes may be listed or referred to in the open literature.

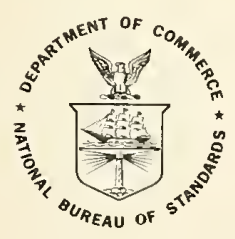

U.S. DEPARTMENT OF COMMERCE, Frederick B. Dent, Secretary NATIONAL BUREAU OF STANDARDS, Richard W. Roberts, Director Issued May 1973 


\section{National Bureau of Standards Technical Note 764}

Nat. Bur. Stand. (U.S.), Tech. Note 764, 31 pages (May 1973)

CODEN: NBTNAE

For sale by the Superintendent of Documents, U.S. Government Printing Office, Washington, D.C. 20402 (Order by SB) Catalog No. C13.46:764).

Price \$0. 50 domestic postpaid or $\$ 0.35$ G.P.O. Bookstore 
In the interest of informing the public on program developments and technical advances within the Division, we are increasing our publications activities, beyond the customary formal publication of complete pieces of work, through the media of NBS Technical Notes and NBS Reports. The former provide the means to deal with the subject matter at greater depth than normally tolerated by today's journal editors and the latter afford an opportunity to describe informally the progress toward current goals where the work is incomplete.

This is a progress report. The work is incomplete and is continuing. Results and conclusions are not necessarily those that will be included in the final, formal publications. The period covered herein is the calendar year 1972 .

H. H. Plumb, Chief

Temperature Section

National Bureau of Standards 


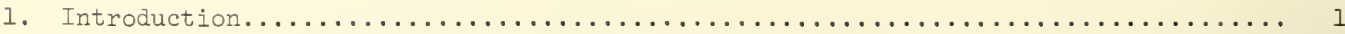

2. High Temperature Stability $\ldots \ldots \ldots \ldots \ldots \ldots \ldots \ldots \ldots \ldots \ldots \ldots \ldots \ldots \ldots \ldots \ldots \ldots \ldots$

2.1. Thermometer Designs................................. 1

2.2. Experimental Procedure................................. 2

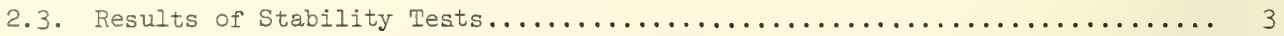

a. Results of Heat Treatment in the Region of $1065^{\circ} \mathrm{C} \ldots \ldots \ldots \ldots \ldots \ldots$

b. Results of Heat Treatment at $960^{\circ} \mathrm{C}$ and $900^{\circ} \mathrm{C} \ldots \ldots \ldots \ldots \ldots \ldots \ldots$

3. Stability of Themometer Resistance at the Freezing Point of Zinc........... 5

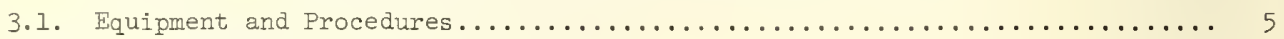

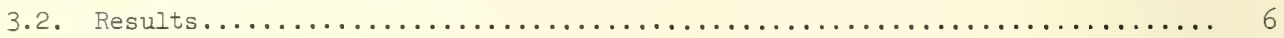

4. Investigations of Thermometer Insulation Resistance.................. 8

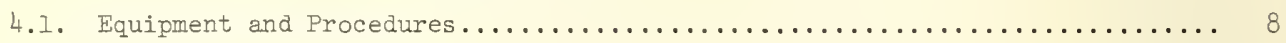

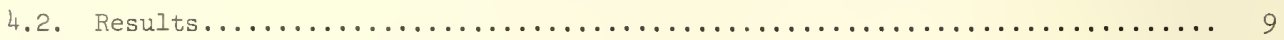

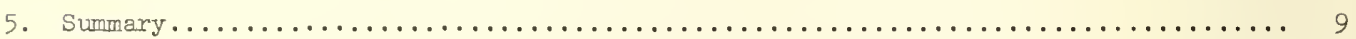

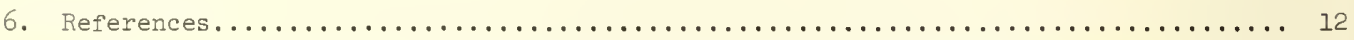

Figure 1. Details of the silica-glass support for the cross (HTFQ) thermometers.

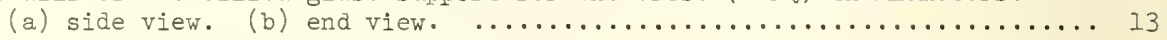

Figure 2. Behavior of four birdcage (HTSS) thermometers and thermometer W-I with exposure to temperatures in the region of $1065^{\circ} \mathrm{C}$. Open symbols were not used in computing drift rates. The temperature scale does not apply strictly to $\mathrm{W}-1$.

Figure 3. Behavior of birdcage thermometer HTSS-16 with exposure to temperatures in the region of $1065^{\circ} \mathrm{C}$. The first point was not used in computing the drift rate.

Figure 4. Effects of various annealing patterns on birdcage themometer HTSS-15 after heating in the region of $1065^{\circ} \mathrm{C}$.

Figure 5. Behavior of cross (HTFQ) thermometers. (a) Exposed to $1065^{\circ} \mathrm{C}$. The first point in each case was not used in computing the drift rate.

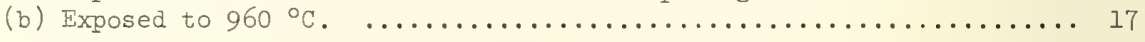

Figure 6. Behavior of the tungsten thermometer $\mathrm{W}-1$. (a) Exposed at $1065{ }^{\circ} \mathrm{C}$.

(b) Exposed at $960{ }^{\circ} \mathrm{C}$. Note different scales. ................... 18

Figure 7. Drift rate of $\mathrm{W}-1$ as a function of time spent at $1065{ }^{\circ} \mathrm{C} . \ldots \ldots \ldots$

Figure 8. Behavior of birdcage thermometers (HTSS) after exposure at $960{ }^{\circ} \mathrm{C}$ and $900{ }^{\circ} \mathrm{C} .20$

Figure 9. Details of the construction of the core of the low temperature furnace and of the hermetically sealed freezing-point-of-zinc cell. 
Figure 10. Circuit diagram of the apparatus used to measure insulation

resistance at low frequencies. $R_{\mathrm{r}}$ is the leakage resistance

being measured, e is the point at which the leakage current

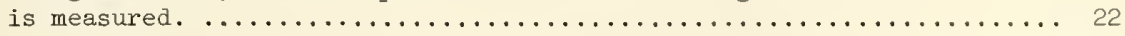

Figure 11. Summary of tests of insulation resistance of $H T F Q-23 . \ldots \ldots \ldots \ldots \ldots$

Figure 12. Typical sets of data for the insulation resistance of HTFQ-23 at

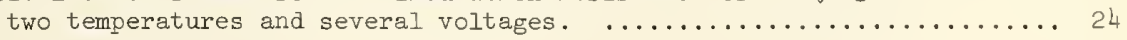



An Investigation of the Stability of and Insulation Leakage in

Some High Temperature Resistance Thermometers: An Interim Report

Sharrill D. Wood

Data are presented concerning the stability of high temperature resistance thermometers. Two types of platinum and one type of tungsten thermometer were tested at $1065{ }^{\circ} \mathrm{C}$ and $960{ }^{\circ} \mathrm{C}$. Some of the platinum thermometers were also tested at $900{ }^{\circ} \mathrm{C}$ and at the freezing point of zinc. Results of tests are also given on the insulation resistance of sensor supports and lead assemblies for the two types of platinum thermometers. A new design for a zinc-point cell is discussed briefly. Suggestions for future work are indicated.

Key words: Freezing point of zinc; high temperature resistance thermometer; insulation resistance; platinum resistance thermometer; resistance thermometer; stability: tungsten thermometer; zinc.

\section{Introduction}

Two main paths of investigation have been followed recently in the high temperature platinum resistance thermometry laboratory at the National Bureau of Standards; one is thermometer stability and the other is thermometer insulation resistance. Drifts and instability in thermometer resistance have long been problems for high temperature resistance thermometers when they are cycled between high temperatures (up to $1100{ }^{\circ} \mathrm{C}$ ) and room temperature. Typically, a thermometer is subjected to a high temperature for a short time (e.g., one hour) and then quenched fairly rapidly upon removal from the furnace or the freezing point apparatus. It would be ideal if the resistance of a thermometer were independent of the thermal treatment it received, but strain and quenching are two well known mechanisms which can change the thermometer resistance. Researchers have tried to eliminate strain through design. Recent changes in annealing procedures [l] have eliminated much of the instability due to quenching found in thermometers, but drift and unstable behavior from these and other sources remain problems. In an effort to test the stability of various configurations and materials, we have conducted some long-range stability tests on three styles of thermometers.

\section{High Temperature Stability \\ 2.1. Thermometer Designs}

We had available six thermometers of the birdcage design [2]. The elements of these thermometers contained synthetic sapphire insulators and were designated high temperature synthetic sapphire or HTSS. The lead wires were strung through small silica glass or alumina tubes and were separated by silica glass, synthetic sapphire, or alumina disks. The insulating disks were more closely spaced near the sensing element of the thermometer to reduce radiation losses. Three of these thermometers (HTSS-14, HTSS-15, and HTSS-16) were relatively old (1960), but had not been used for several years. (HTSS-14 was studied in [2].) The elements and leads were remounted in $800 \mathrm{~mm}$ long, high-purity silica-glass sheaths. This required extending the leads but the elements were not modified. Two of the thermometers (HTSS-21 and HTSS-22) were new; their elements had been made earlier but the leads had not been attached. The sixth thermometer (HTSS-19) was an old thermometer (1961) which had been used during the intercomparison of high temperature thermometers and thermocouples [3]. Table 1 contains a summary of the characteristics of the thermometers that were investigated. 
Serial Number
HTSS-1 4
HTSS-15
HTSS -16
HTSS-19

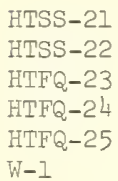

\section{Coil Support}

synthetic sapphire synthetic sapphire synthetic sapphire synthetic sapphire

synthetic sapphire synthetic sapphire silica glass silica glass silica glass tungsten

\begin{tabular}{ccl}
$\begin{array}{c}\text { Lead Assembly } \\
\text { Insulators }\end{array}$ & $\mathrm{R}_{0}, \Omega$ & \multicolumn{1}{c}{ Style } \\
alumina & 0.26295 & Birdcage \\
alumina & 0.26983 & $\begin{array}{l}\text { Birdcage } \\
\text { alumina }\end{array}$ \\
$\begin{array}{c}0.26099 \\
\text { Blumina tubes }\end{array}$ & 0.26048 & Birdcage \\
synthetic sapphire & & \\
disks & & \\
silica glass & 0.25778 & Birdcage \\
alumina & 0.25950 & Birdcage \\
silica glass & 0.22921 & Cross \\
silica glass & 0.22248 & Cross \\
silica glass & 0.21790 & Cross \\
silica glass & 0.2580 & Steeple
\end{tabular}

Three resistance thermometers of a new element design were constructed and tested for their stability. Platinum wire, $0.4 \mathrm{~mm}$ diam, was wound in a bifilar helix around a cross shaped silica-glass support (fig. I) made at the National Bureau of Standards. Thermometers of a similar design have been investigated by Sawada and Mochizuki [4]. The resistance of the thermometers at the triple point of water is nominally $0.25 \Omega$; these cross thermometers were designated high temperature fused quartz or HTFQ. Before assembly all silica glass parts were cleaned by an ultrasonic technique in sequential baths of trichloroethylene, methyl alcohol, and distilled water, and then fired in oxygen at $1100{ }^{\circ} \mathrm{C}$ for one hour. The sheath was cleaned by washing with a detergent and then rinsing extensively with distilled water. It was dried by heating to a low temperature. Finally, it was fired for one hour at $1100{ }^{\circ} \mathrm{C}$ in oxygen. After assembly but before being inserted in the sheath, the thermometer was soaked in aqua regia for three hours, rinsed with distilled water, and baked at temperatures up to $600^{\circ} \mathrm{C}$. After being placed in the silica-glass sheath, the thermometer was evacuated, fired in oxygen for five minutes at $1100^{\circ} \mathrm{C}$, and reevacuated. The sheath was then sealed after being filled with dry air to a pressure of one atmosphere at $1065^{\circ} \mathrm{C}$. The same general technique was followed in the construction of the birdcage thermometers .

The resistance element of the third type of thermometer was fabricated from thoriadoped tungsten wire. The element was made by R. I. Anderson while he was at the National Bureau of Standards and it was built in the style of a "steeple" thermometer [5]. The thermometer leads are $W-3 \%$ Re alloy wires of $0.37 \mathrm{~mm}$ diam and the lead assembly insulators are silica glass disks and tubes. Initially, the element was annealed at $2000^{\circ} \mathrm{C}$ for one hour before the thermometer was assembled and afterwards the fabricated thermometer, designated $W-1$, was vacuum baked at $800^{\circ} \mathrm{C}$ and filled with argon gas. Only one tungsten resistance thermometer was tested.

\subsection{Experimental Procedure}

The procedure followed in testing the long-term stability was the same for the three types of thermometers. Resistance readings were first taken at the triple point of water. The thermometers were then placed in a pre-heated furnace where they remained for a specified period of time after which they were annealed. Then triple-point resistance readings were taken again. These tests differ from normal use of the thermometers in two important respects. First, the thermometers are exposed to high temperatures for a longer time than in normal usage. Second, the thermometers are not quenched before annealing.

Repeated measurements at the triple point of water without intervening heat treatment show that the average difference in 20 successive pairs of readings is $0.04 \mathrm{mK}$ and the standard deviation is $0.28 \mathrm{mK}$. This represents the reproducibility of our measuring system and thermometers. One cross and four birdcage thermometers were used to obtain these data. 


\section{a. Results of Heat Treatment in the Region of $1065^{\circ} \mathrm{C}$}

Figures 2, 3 and 4 summarize the results of tests for thermometer $W-1$ at $1065{ }^{\circ} \mathrm{C}$, and for five birdcage thermometers at $1100{ }^{\circ} \mathrm{C}$, at $1065{ }^{\circ} \mathrm{C}$, and at the freezing point of gold. Thermometer HTSS-16 (fig. 3) was tested much longer than the others because of its unstable behavior. Thermometer HTSS-2l was resheathed twice in the course of the experiment and data is given for the most recent sheath only.

There was a relatively large initial shift in the ice-point resistance for all five birdcage thermometers as a result of the heat treatment. This is probably caused by the annealing of cold working done during construction. Thermometer HTSS-14 continued to drift rapidly for a fairly long period of time but it had been dropped while out of its sheath prior to these tests and had thereby suffered a large amount of cold working and possibly slight contamination. Thermometer HTSS-22 was the only one that exhibited an initial increase in the ice-point resistance. Thermometer HTSS-2I, after the initial decrease in the ice-point resistance, continued to increase in resistance with additional exposure to high temperatures.

Figure 4 is essentially an enlargement of a part of figure 2. From it, we can see the effects of various annealing patterns. The first four points represent the resistance at the ice point following an anneal of rapid cooling from $1065{ }^{\circ} \mathrm{C}$ to $650{ }^{\circ} \mathrm{C}(1.5 \mathrm{~h})$, one hour at $650^{\circ} \mathrm{C}$, and slow cooling to room temperature. The thermometer was not quenched from $1065{ }^{\circ} \mathrm{C}$ prior to annealing. The next six points were taken after a quench from the gold point to room temperature, one hour at $650^{\circ} \mathrm{C}$, and slow cooling to room temperature over night. The last eight points were taken after a new annealing pattern which is based on the work of Berry [1]. The thermometer was placed in a furnace at $1065{ }^{\circ} \mathrm{C}$ (following a quench from the gold point to room temperature) and the furnace temperature was slowly lowered to $450{ }^{\circ} \mathrm{C}$ at a rate of $90^{\circ} \mathrm{C} / \mathrm{h}$. For some of these last points, the thermometer was not quenched but had been in the annealing furnace at $1065{ }^{\circ} \mathrm{C}$ for several hours when the anneal began. The shift in the ice-point resistance after the first gold point was not removed by an anneal of one hour at $650{ }^{\circ} \mathrm{C}$ followed by slow cooling. The new annealing procedure was removed most of the quenched-in shift and brought the ice-point resistance closer to its original curve.

Figure 5a gives the results of the heat treatment of the three cross thermometers at $1065^{\circ} \mathrm{C}$. These thermometers were found to be generally more stable than the birdcage thermometers and to behave remarkably similarly. They were constructed at nearly the same time from the same lots of materials and HTFQ-24 and HTFQ-25 had the same thermal history. Thermometer HTFQ-23 had been used in the insulation resistance tests prior to the long-term stability tests and was subsequently repaired and resheathed. However, this treatment does not seem to have affected it to any noticeable extent.

Figures $6 \mathrm{a}$ and 2 give the results of testing the tungsten thermometer, W-I, at $1065{ }^{\circ} \mathrm{C}$. We can see from figure 6 a that the thermometer had not been well stabilized when the tests began. From figure 7, we see that after approximately 400 hours at $1065^{\circ} \mathrm{C}$ and above, the drift rate reached $I \mu \Omega / h$. The rate of change of the ice-point resistance seems to be an exponential function of the time at elevated temperatures. In figure 2, it is seen that the drift rate of $\mathrm{W}-1$ is approaching that of some of the birdcage thermometers.

\section{b. Results of Heat Treatment at $960^{\circ} \mathrm{C}$ and $900^{\circ} \mathrm{C}$}

The results of heat treatment at $960^{\circ} \mathrm{C}$ for the birdcage thermometers are given in figure 8. These data were taken after the work at $1065^{\circ} \mathrm{C}$. As might be expected, the stability is better than the stability at $1065^{\circ} \mathrm{C}$. Thermometer HTSS-16 is still relatively unstable and HTSS-14 is still drifting. This may possibly be due to its gross cold working during construction but is more likely an "equilibrium" drift rate.

From figure $5 \mathrm{~b}$ we see that the cross thermometers are well behaved at $960{ }^{\circ} \mathrm{C}$. Two measurements at the zinc point were taken with each thermometer between the work at $1065{ }^{\circ} \mathrm{C}$ and these data. Thermometer HTFQ-24 was found to be more stable than the others but the 
range of drift rates is only $0.02 \mathrm{mK} / \mathrm{h}$. Only HTSS-16 and HTSS-2l had such small drift rates at $960^{\circ} \mathrm{C}$ and they showed greater variability.

Thermometer $W-1$ ( $f i g .6 b$ ) was found to drift considerably less as a result of heating at $960^{\circ} \mathrm{C}$ than from heating at $1065^{\circ} \mathrm{C}$. These measurements followed the work at $1065^{\circ} \mathrm{C}$. Its drift rate is still the largest of all the thermometers and it is difficult to tell if the drift rate is decreasing exponentially as was the case at $1065^{\circ} \mathrm{C}$.

The ice-point resistances or the birdcage thermometers resulting from heating at $900{ }^{\circ} \mathrm{C}$ are shown in figure 8 . These experiments were preceded by the work at $960{ }^{\circ} \mathrm{C}$ and by measurements at the zinc point for some of the thermometers. These six thermometers, when heated at this temperature, exhibited drift rates that were equivalent to the drift rates of the cross thermometers at $960^{\circ} \mathrm{C}$ and were less variable than the cross thermometer drift rates at $960{ }^{\circ} \mathrm{C}$.

It should be noted that the heat treatments given the birdcage and cross thermometers differed in two respects. The birdcage thermometers were never continuously at a high temperature for more than twenty hours while the cross thermometers were often at a high temperature for one hundred hours at one time. Any change in the ice-point resistance which was not time dependent would be expected to have a larger effect on the drift rate of the birdcage themometers because they were cycled more frequently than the cross thermometers. The second difference is that the cross thermometers were never given any short cycles in the gold-point cell followed by quenching. Any quenching effects that were not removed during annealing would affect only the birdcage thermometers. However, we feel that our current annealing procedure is removing noticeable quenched-in defects.

Drift rates given in this paper are the change in the ice-point resistance (calculated from the triple point resistance and corrected to zero current) per hour of exposure at elevated temperatures. The drift rates that were obtained are summarized in table 2 for the three types of thermometers at the temperatures at which they were tested. These drift rates were computed by fitting a straight line, using the least squares procedure in OMVITAB [6], to the observed values of the ice point resistances as a function of the time of exposure to high temperatures. Also, given in table 2 are the residual standard deviations and their associated degrees of freedom. The residual standard deviation is a measure of the scatter of the data points about the straight line fitted through them; it is not a measure of the variability of the y-intercept or of the slope of the line. These variabilities are given by the standard deviations of the coefficients found for the straight line. The standard deviation of the slope (drift rate) was in all cases $30 \%$ or less of the drift rate, and in all but three cases it was $15 \%$ or less.

Table 2. Drift Rates

\begin{tabular}{|c|c|c|c|c|c|c|c|c|c|c|}
\hline Serial Number & $\begin{array}{c}\text { HTSS } \\
14 \\
\end{array}$ & $\begin{array}{c}\text { HTSS } \\
15 \\
\end{array}$ & $\begin{array}{c}\text { HTSS } \\
16 \\
\end{array}$ & $\begin{array}{c}\text { HTSS } \\
19 \\
\end{array}$ & $\begin{array}{c}\text { HTSS } \\
21 \\
\end{array}$ & $\begin{array}{c}\text { HTSS } \\
22 \\
\end{array}$ & $\begin{array}{c}\text { HTFQ } \\
23 \\
\end{array}$ & $\begin{array}{c}\mathrm{HTFQ} \\
24 \\
\end{array}$ & $\begin{array}{c}\text { HTFQ } \\
25\end{array}$ & $\mathrm{~W}-1$ \\
\hline $\begin{array}{c}1065{ }^{\circ} \mathrm{C} \\
\text { Drift rate } \begin{array}{l}\mu \Omega \\
\mathrm{mK}\end{array}\end{array}$ & $\begin{array}{l}-0.16 \\
-0.15\end{array}$ & $\begin{array}{l}-0.03 \\
-0.03\end{array}$ & $\begin{array}{l}0.21 \\
0.20\end{array}$ & & $\begin{array}{l}0.11 \\
0.11\end{array}$ & $\begin{array}{l}-0.13 \\
-0.12\end{array}$ & $\begin{array}{l}0.07 \\
0.08\end{array}$ & $\begin{array}{l}0.06 \\
0.07\end{array}$ & $\begin{array}{l}0.04 \\
0.05\end{array}$ & 0.30 \\
\hline $\begin{array}{l}\text { Residual standard } \\
\text { deviation, } \mathrm{mK} \\
\text { Degrees of freedom }\end{array}$ & $\begin{array}{c}2.35 \\
18\end{array}$ & $\begin{array}{c}1.05 \\
21\end{array}$ & $\begin{array}{c}6.16 \\
39\end{array}$ & & $\begin{array}{c}3.11 \\
15\end{array}$ & $\begin{array}{c}2.77 \\
21\end{array}$ & $\frac{2.73}{6}$ & $\frac{2.85}{6}$ & $\frac{3.11}{6}$ & $\begin{array}{c}5.82 \\
8\end{array}$ \\
\hline $\begin{array}{c}960^{\circ} \mathrm{C} \\
\text { Drift rate } \begin{array}{c}\mu \Omega \\
\mathrm{mK}\end{array}\end{array}$ & $\begin{array}{l}-0.04 \\
-0.04\end{array}$ & $\begin{array}{l}-0.03 \\
-0.03\end{array}$ & $\begin{array}{l}-0.02 \\
-0.02\end{array}$ & $\begin{array}{l}0.07 \\
0.07\end{array}$ & $\begin{array}{l}0 \\
0\end{array}$ & $\begin{array}{l}0.04 \\
0.04\end{array}$ & $\begin{array}{l}-0.02 \\
-0.02\end{array}$ & $\begin{array}{l}0 \\
0\end{array}$ & $\begin{array}{l}-0.01 \\
-0.01\end{array}$ & 0.10 \\
\hline $\begin{array}{l}\text { Residual standard } \\
\text { deviation, } \mathrm{mK} \\
\text { Degrees of freedom }\end{array}$ & $\begin{array}{l}0.64 \\
10\end{array}$ & $\begin{array}{c}0.37 \\
10\end{array}$ & $\begin{array}{c}1.07 \\
10\end{array}$ & $\begin{array}{c}0.84 \\
10\end{array}$ & $\begin{array}{c}0.68 \\
10\end{array}$ & $\begin{array}{c}1.35 \\
10\end{array}$ & 0.24 & $\frac{0.15}{6}$ & 0.15 & $\frac{2.61}{4}$ \\
\hline
\end{tabular}


Table 2 (continued)

\begin{tabular}{lcccccccccc} 
& HTSS & HTSS & HTSS & HTSS & HTSS & HTSS & HTFQ & HTFQ & HTFQ & \\
Serial Number & 14 & 15 & 16 & 19 & 21 & 22 & 23 & 24 & 25 & W-1 \\
\hline
\end{tabular}

$900{ }^{\circ} \mathrm{C}$

$\begin{array}{lcccccc}\text { Drift rate }{ }_{\mathrm{mK}}^{\mu} & -0.02 & -0.02 & -0.01 & 0.02 & 0 & 0.03 \\ \text { Residual standard } & -0.02 & -0.02 & -0.01 & 0.02 & 0 & 0.03 \\ \quad \text { deviation, mK } & 0.14 & 0.34 & 0.52 & 0.41 & 0.36 & 0.27 \\ \text { Degrees of freedom } & 12 & 12 & 12 & 12 & 12 & 12\end{array}$

It has been pointed out by Curtis [7] that drift rates for very long-term (>1000 hours) experiments often differ substantially from the drift rates for shorter-term experiments. Time did not permit us to test these thermometers beyond a few hundred hours but it would seem unlikely that there would be much difference in the drift rates for long and shortterm heat treatments because most of the thermometers seemed relatively stable. Grain growth could cause a change in the drift rate with time. However, several of the birdcage thermometers were old and three had been at $960^{\circ} \mathrm{C}$ and above for at least 300 hours before these tests.

It would appear from the results that with careful monitoring and sufficient annealing, the long-term stability of the cross thermometers and of four birdcage thermometers is satisfactory, but the stabilities of themometers HTSS-19 and HTSS-16 are not good. One can say little at this time about the tungsten resistance thermometer, except that better initial stabilization procedures must be found and that with proper stabilization, its performance could approach the birdcage thermometers.

\section{Stability of Thermometer Resistance at the Freezing Point of Zinc}

\subsection{Equipment and Procedures}

We have recently installed a new type of freezing-point-of-zinc cell. Because of earlier problems with contamination of cells [3], it was decided that hermetically sealed cells were necessary. The cell ( $\mathrm{fig} .9$ ) was made from borosilicate glass and the crucible and thermometer well were made from high-purity graphite. In addition to being shorter in overall length and offering a greater depth of immersion than the old cell, the new cell has a double thermometer well. Next to the zinc is a graphite well, and between that well and the thermometer sheath is a borosilicate-glass well which is an integral part of the cell. We have not noticed any particular problems of inadequate immersion or heat transfer because of this double well arrangement. Melting curves indicate that the zinc in the new cell is not as pure as the zinc in the old cell (which is not hermetically sealed).

In addition to protecting the zinc from contamination, the new cell design has allowed us to modify our low temperature furnace. Because of the small size of the cell, the aluminum moderating block in the furnace could be removed and replaced with an aluminum "can" (fig. 9). The zinc cell was placed inside this can. In this way, the cell was surrounded on all sides by aluminum. The furnace windings were simplified and now only a single winding is used. The old furnace and zinc cell are described in [3]. Initial tests with a $25-\Omega$ standard platinum resistance thermometer indicated that the thermometer can track the temperature gradient due to the hydrostatic pressure of the liquid metal over $7 \mathrm{~cm}$ to within $20 \mu \mathrm{K}$.

In the course of testing the new zinc cell, we also gathered some data on the performance of the thermometers. Initial resistance measurements at the zinc point were taken with the birdcage thermometers after their stability tests at $960{ }^{\circ} \mathrm{C}$, and the final measurements at the zinc point were taken after the tests at $900{ }^{\circ} \mathrm{C}$. The resistances of the cross thermometers were studied at the zinc point before and after exposure at $960{ }^{\circ} \mathrm{C}$. Occasionally, consecutive measurements were taken during one freeze. During this procedure, the thermometer was allowed to attain thermal equilibrium with the freezing zinc, resistance readings were taken, and the thermometer was removed for five minutes. The thermometer was 
then reinserted and the process repeated. Up to three sets of readings were taken during a single freeze. Sometimes, several thermometers were tested during one freeze. The same procedure was followed with the exception that a different thermometer was introduced into the zinc-point cell after the five minute wait.

\subsection{Results}

The changes in thermometer resistances at the zinc point, in mK equivalents, are summarized in table 3. The birdcage thermometers had an initial shift in their zinc-point resistances of $-1.2 \mathrm{mK}$ to $9.9 \mathrm{mK}$. These values are based on an average of the observed changes in terms of $R_{Z n}, W_{Z n}$, and $D_{Z n}$, where $R_{Z n}$ is the thermometer resistance at the freezing point of zinc,

$$
\text { and } \begin{aligned}
W_{Z n} & =R_{Z n} / R_{0}, \\
D_{Z n} & =R_{Z n}-R_{0} .
\end{aligned}
$$

$R_{0}$ is the average of the ice-point resistances read before and after the zinc point. In some cases, the ice-point resistance changed more than the zinc-point resistance but no pattern emerged for the four birdcage thermometers. After the shift, the thermometers stabilized but they were not quite as stable as the cross thermometers.

\section{Table 3. Zinc Point Data}

\begin{tabular}{|c|c|c|c|c|}
\hline RT & $\Delta \mathrm{R}_{\mathrm{Zn}}$ & $\Delta W_{Z n}$ & $\Delta \mathrm{D}_{\mathrm{Zn}}$ & $\Delta \mathrm{R}_{0}$ \\
\hline HTSS-14 & $\left.\begin{array}{c}0^{*} \\
-4.6 \\
1.7 \\
0 \\
-0.8\end{array}\right\} \quad(a)$ & $\begin{array}{r}0^{*} \\
11.9 \\
1.9 \\
0 \\
-0.8\end{array}$ & $\begin{array}{r}0^{*} \\
1.8 \\
1.8 \\
0 \\
-0.8\end{array}$ & $\begin{aligned} & 0^{*} \\
&-5.7 \\
&-0.1 \\
& 0 \\
& 0\end{aligned}$ \\
\hline HTSS-16 & $\left.\begin{array}{c}0^{*} \\
4.4 \\
0.4 \\
-0.3 \\
-0.4\end{array}\right\}$ & $\begin{array}{c}0 * \\
16.3 \\
6.4 \\
-0.3 \\
-0.4\end{array}$ & $\begin{aligned} & 0^{*} \\
& 9.0 \\
& 2.7 \\
&-0.2 \\
&-0.5\end{aligned}$ & $\begin{array}{r}0^{*} \\
-4.1 \\
-2.1 \\
0 \\
0\end{array}$ \\
\hline HTSS-2I & $\left.\begin{array}{c}0 * \\
8.3 \\
0.6 \\
0.7 \\
-0.3\end{array}\right\}$ & $\begin{array}{l}0^{*} \\
9.7 \\
0.6 \\
0.7 \\
-0.3\end{array}$ & $\begin{aligned} & 0^{*} \\
& 8.8 \\
& 0.6 \\
& 0.7 \\
&-0.2\end{aligned}$ & $\begin{aligned} & 0^{*} \\
&-0 . 4 \\
& 0 \\
& 0 \\
& 0\end{aligned}$ \\
\hline HTSS-22 & $\left.\begin{array}{r}0^{*} \\
9.9 \\
0.3 \\
0.1\end{array}\right\}$ & $\begin{array}{c}0^{*} \\
-14.2 \\
0.4 \\
0.1\end{array}$ & $\begin{array}{l}0^{*} \\
0.5 \\
0.4 \\
0\end{array}$ & $\begin{array}{c}0^{*} \\
-8.2 \\
0 \\
0\end{array}$ \\
\hline HTFQ-23 & $\left.\begin{array}{r}0^{* *} \\
1.0^{* *} \\
17.1 \\
0.5 \\
-2.4 \\
3.0 \\
0.2 \\
0.2 \\
0.3 \\
-0.2\end{array}\right\}$ & $\begin{array}{r}0 * * \\
1.1 * * \\
34.2 \\
0.9 \\
-2.3 \\
2.6 \\
0.6 \\
0.1 \\
0.3 \\
-0.2\end{array}$ & $\begin{array}{r}0 * * \\
1.0 * * \\
23.8 \\
0.7 \\
-2.4 \\
2.9 \\
0.3 \\
0.2 \\
0.3 \\
-0.2\end{array}$ & $\begin{array}{r}0^{* *} \\
0^{* *} \\
-5.8 \\
-0.1 \\
0 \\
0.2 \\
-0.1 \\
0 \\
0 \\
0\end{array}$ \\
\hline
\end{tabular}

Difference from preceding zine point, $x_{i+1}-x_{i}, m K$ 
Table 3 (continued)

\begin{tabular}{|c|c|c|c|c|}
\hline $\mathrm{RT}$ & $\Delta \mathrm{R}_{\mathrm{Zn}}$ & $\Delta W_{Z n}$ & $\Delta D_{\mathrm{Zn}}$ & $\Delta R_{0}$ \\
\hline $\mathrm{HTFQ}-24$ & 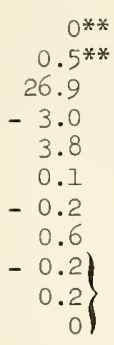 & $\begin{array}{r}0^{* *} \\
0.1 * * \\
30.0 \\
-2.9 \\
4.0 \\
0.3 \\
0.3 \\
0.7 \\
-0.5 \\
0.2 \\
0\end{array}$ & $\begin{array}{r}0 * * \\
0.3^{* *} \\
28.1 \\
-2.9 \\
3.9 \\
0.2 \\
0 \\
0.6 \\
-0.3 \\
0.2 \\
0\end{array}$ & $\begin{array}{r}0^{*}- \\
0 . I^{*} \\
-1.0 \\
0 \\
-0.1 \\
-0.1 \\
-0.2 \\
0 \\
0.1 \\
0 \\
0\end{array}$ \\
\hline HTFQ-25 & $\begin{array}{r}0 * * \\
1.3^{* *} \\
17.9 \\
0.2 \\
\left.-\begin{array}{l}0.5 \\
0.6 \\
0.1 \\
0.1 \\
0.1\end{array}\right\}\end{array}$ & $\begin{array}{r}0^{* * *} \\
1.1 * * \\
32.0 \\
0.4 \\
-0.2 \\
0.8 \\
-0.1 \\
0.1 \\
0.1\end{array}$ & $\begin{aligned} & 0^{* *} \\
& 1.2^{* *} \\
& 23.4 \\
& 0.3 \\
&-0.4 \\
& 0.7 \\
& 0 \\
& 0.1 \\
& 0.1\end{aligned}$ & $\begin{array}{r}0 * \\
0 * \\
-4.8 \\
-0.1 \\
0.1 \\
-0.1 \\
-0.1 \\
0.1 \\
0\end{array}$ \\
\hline
\end{tabular}

* data taken before exposure to $900{ }^{\circ} \mathrm{C}$
* data taken before exposure to $960{ }^{\circ} \mathrm{C}$

(a) bracketed runs were taken during the same freeze.

The cross thermometers showed a large initial increase of $20 \mathrm{mK}$ to $30 \mathrm{mK}$ in the zincpoint resistance. Because the ice-point readings remained relatively steady over the entire time that zinc-point readings were taken, strain and improper annealing do not seem to be the source of all the instability. It is particularly noteworthy that the ice-point resistance decreased while the zinc-point resistance increased. This would definitely point away from strain as the source of the change. Part of the increase may be due to the increasing devitrification of the initially clear silica glass sheath which results in the reduction of the radiation "piped" up the sheath. McLaren [8] has shown that errors equal to or exceeding $16 \mathrm{mK}$ may be due to radiation losses up the stem of a standard $25-\Omega$

thermometer. However, we might expect to find less than this because the sheaths devitrified only slightly during testing at $960^{\circ} \mathrm{C}$.

Another source of the observed change might be a change in the pressure in the zine cell. If a leak had developed, the cell pressure would tend to approach one atmosphere at room temperature and 2.3 atmospheres at $420^{\circ} \mathrm{C}$. However, a pressure change of 1.3 atmospheres would cause the zine point to change by $5.6 \mathrm{mK}$ and this does not explain our large shift.

Perhaps the zinc had somehow become contaminated between the last measurements with the birdcage thermometers and the last measurements with the cross thermometers. It was not removed from the furnace during the course of these measurements but let us postulate that something unusual happened. A $25-\Omega$ thermometer was used to monitor the zinc point over the eight month period in question, and it showed a total change in the zinc point of $0.7 \mathrm{mK}$. Therefore, it seems clear that the thermometers have changed. We do not know whether they changed gradually during the 300 hours at $960^{\circ} \mathrm{C}$ or suddenly. In either case, we conclude that it may be necessary to monitor the zinc point or some other suitable fixed point, as 
well. as the triple point of water, during long-term stability tests.

After the shift in the resistance at the zinc point had occurred, the thermometers behaved in a stable manner. The fifth zinc point on HTFQ-23 and the fourth on HTFQ-24 (table 3) were measured consecutively during a continuous freeze. The plateau began to fall off shortly after HTFQ-24 was inserted. Previously, plateaux had usually lasted two hours but this one began to decrease after only one hour. All the following zinc-point measurements agreed with the first zinc points after the initial shift, and it was felt that the freeze had not progressed properly. These two points met the Dixon criterion [9] for rejection for $\alpha=0.01$ and so the runs were discounted.

Values of the zinc-point resistance of the cross thermometers following the large initial shift (with the exception of the two measurements noted above) were quite well behaved. The maximum observed change within this stable subset of readings was $1.1 \mathrm{mK}$ and. most of the changes were considerably smaller and positive. This is in keeping with our observations of the birdcage thermometers. The average changes in the resistance at the zinc point (based on an average of $R_{7 n}, W_{7 n}$, and $D_{7 n}$ ) from one freeze to the next were 0.02 , 0.2 and 0.1 mK for the three cross thermometers with standard deviations of $0.3,0.4$, and $0.5 \mathrm{mK}$, respectively.

We do not know whether the changes in the zinc-point resistances of the cross thermometers following the work at $960^{\circ} \mathrm{C}$ were larger than the changes in the zinc-point resistances of the birdcage thermometers because the intermediate temperature was $960^{\circ} \mathrm{C}$ instead of $900^{\circ} \mathrm{C}$ in the case of the birdcage thermometers or because there is some inherent characteristic in the cross thermometers which caused the charge. One way to check this would be to perform the experiment using $900^{\circ} \mathrm{C}$ as the intermediate temperature for the cross thermometers or using $960^{\circ} \mathrm{C}$ for the birdcage thermometers.

\section{Investigations of Thermometer Insulation Resistance}

The birdcage thermometer was designed to proviaje a strain-free element and a small resistance which would reduce the effects of the electrical insulation leakage that shunts the sensor. A 25- $\Omega$ thermometer must have insulation resistance in the lead assembly and coil support of at least $25 \mathrm{M} \Omega$ at the triple point of water if the effect of the shunting is to be less than 1 in $10^{6}$. A $0.25-\Omega$ thermometer needs only 1 M $\Omega$ of insulation resistance at the gold point to keep the effects of shunting below 1 in $10^{6}$.

\subsection{Equipment and Procedures}

To check the insulation resistance of the cross thermometers, a special thermometer was constructed. Its construction was similar to the other cross thermometers, except that the thermometer element was cut at its mid-point. In this way we could measure, under realistic conditions, the insulation resistance of the element suppcrt anô lead̆ assembly as a function of temperature, frequency, and voltage. A less extensive investigation was carried out with a birdcage thermometer (HTSS-22), which had a fifth "lead" wire runing from just above (but not touching) the sensing element to outside the thermometer head. The measurements, though not as ideal as measurements with the cross thermometer, were useful.

Two measurement systems were used. For the higher frequencies (50 to $1000 \mathrm{hz}$ ), a capacitance bridge was used anc resistance values were read from the bridge. For the lower frequencies $\left(10^{-3}\right.$ to $10^{-1} \mathrm{hz}$ ), the circuit shown in figure 10 was used. $R_{m}$ is the shunting insulation resistance, and $e$ is the measured voltage across a $100 \Omega$ resistōr. The leakage current through the thermometer is supplied by a dry cell and is $i_{L}=e / l 00$. Hence, the leakage resistance, $R_{T}$, is given by

$$
R_{T}=V / i_{L}=100 \mathrm{~V} / \mathrm{e} .
$$

Measurements of e were made by connecting a strip chart recorder across the $100 \Omega$ resistor. The voltage $V$, applied across the thermometer, was established using a resistor of known value $\left(10^{5}\right.$ or $10^{6} \Omega$ ) in place of $R_{m}$ and adjusting the slidewire. The current was reversed by manual switching. All measuremerts at $600^{\circ} \mathrm{C}$ and above were made in the gold-point cell 
to approximate the conditions of actual use. The resistances at $0{ }^{\circ} \mathrm{C}$ were determined from measurements taken in a triple-point-of-water cell.

\subsection{Results}

Figures 11 and 12 give the results of these tests for the cross thermometer. It would seem that an insulation resistance of $I M \Omega$ is not as easily achieved as we had initially thought [3]. Below $850{ }^{\circ} \mathrm{C}$, the insulation resistance exceeded $1 \mathrm{M} \Omega$. There was very little dependence on frequency or voltage until the temperature dropped below $700{ }^{\circ} \mathrm{C}$. Thus, the frequency dependence of the insulation resistance is a problem with ac resistance bridges. These results indicate that researchers should make measurements whenever possible to determine the magnitude of shunting errors under their operating procedures.

Figure 12 presents typical sets of data on insulation resistance for two temperatures at several frequencies and voltages. For the lower temperatures, there is a larger difference between the $10 \mathrm{~V}$ and $1 \mathrm{~V}$ readings than is observed at the higher temperatures. Although higher voltages yielded higher insulation resistances, voltages above $\mathrm{l} V$ should not be used. Since the insulators do not obey Ohm's law, voltages should be kept as small as is practical. Although the actual value used in thermometry is less than $I \mathrm{~V}$, we see that the change between $\mathrm{IV}$ and $0.1 \mathrm{~V}$ is small so the value chosen below $\mathrm{I}$ is not critical.

The insulation resistances measured in the birdcage thermometer were of the same order of magnitude as the cross thermometer resistances. The resistance at $1065^{\circ} \mathrm{C}$ was $0.5 \mathrm{M} \Omega$ at frequencies between 50 and $1000 \mathrm{hz}$. The insulation resistance at $0{ }^{\circ} \mathrm{C}$ is given in table 4. There is less than an order of magnitude difference between the two types of thermometers.

\section{Table 4. Insulation Resistance of HTSS-22 at $0{ }^{\circ} \mathrm{C}$}

Frequency, hz

50

100

200

400

1000
Resistance, $M \Omega$

$$
8.4 \times 10^{3}
$$

$2.1 \times 10^{4}$

$1.0 \times 10^{4}$

$4.7 \times 10^{3}$

$1.8 \times 10^{3}$

We observed considerable polarization of the insulators at the low frequencies; the initial resistance after the switch was reversed changed exponentially with time. The effects of polarization were not examined at higher frequencies ( $\geqslant 50 \mathrm{hz}$ ) but some polarization may have occurred.

Additional work is planned with different configurations and materials for thermometer elements. The frequency dependence of the insulation resistance is expected to be a problem. Therefore, more data on other insulators, e.g., Beo, are needed before ac resistance bridges can become standard laboratory instruments. More data must be taken in the mid-frequency range $(0.01$ to $50 \mathrm{hz}$ ) because the frequency-resistance curve appears to break in this region.

\section{Summary}

The results of the stability tests were, for the most part, encouraging. All drift rates of three types of thermometer as a result of heat treatments at the temperatures discussed were equal to or less than $0.3 \mathrm{mK} / \mathrm{h}$ and most were less than $0.1 \mathrm{mK} / \mathrm{h}$. The residual 
standard deviations of most of the thermometers about the straight line fit to the data were small. It appears that the cross thermometers were slightly more stable and less subject to drift than the birdcage thermometers. The stability of thermometer HTSS-15 was outstanding among the birdcage thermometers (even among the cross thermometers). The results of the heat treatments of themometers HTSS-16 at $1065{ }^{\circ} \mathrm{C}$ and HTSS-19 at $960{ }^{\circ} \mathrm{C}$ showed them to be the least stable and the least satisfactory.

The reproducibility of the cross thermometers at the high temperature fixed points (silver and gold) will have to be tested. They have not been cycled "rapidly" (>20 hours of exposure to high temperatures) nor have they been quenched before annealing with the exception of two or three sets of measurements at the silver point taken with each thermometer after the second set of measurements at the zinc point. The results of these measurements are given in table 5 .

\section{Table 5. Silver Point Data}

$$
\text { Difference from preceding silver point, } X_{i+1}-X_{i}, m K
$$

\begin{tabular}{|c|c|c|c|c|}
\hline $\mathrm{RT} S / \mathbb{N}$ & $\Delta \mathrm{R}_{\mathrm{Ag}}$ & $\Delta W_{A g}$ & $\Delta \mathrm{D}_{\mathrm{Ag}}$ & $\Delta \mathrm{R}_{\mathrm{C}}$ \\
\hline \multirow[t]{4}{*}{$H T F Q-23$} & $0)$ & 0 & 0 & 0 \\
\hline & $1.9\}(a)$ & 1.8 & 1.9 & 0 \\
\hline & -0.8 & -1.5 & -1.0 & 0.1 \\
\hline & 2.1 & 2.3 & 2.1 & 0 \\
\hline \multirow[t]{2}{*}{ HTFQ-24 } & 0 & 0 & 0 & 0 \\
\hline & 0.6 & 0.4 & 0.6 & 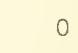 \\
\hline \multirow[t]{2}{*}{$H T F Q-25$} & 0 & 0 & 0 & 0 \\
\hline & -0.5 & -0.4 & -0.3 & -0.1 \\
\hline
\end{tabular}

(a) bracketed runs were taken during the same freeze.

The birdcage thermometers were not as steady at the zinc point as the cross thermometers but they did not exhibit the large initial shift found with the cross thermometers. Further research will have to be carried out to probe the mechanism of the shift. Thermometer resistances at the zinc point (and perhaps the tin point) should be monitored more frequently during exploratory stability tests at $960{ }^{\circ} \mathrm{C}$ and above.

Insulation leakage is a problem. The frequency dependence of the leakage must be carefully investigated in light of the increasing popularity of ac resistance bridges. Work is planned to investigate both silica glass and sapphire in both the birdcage and cross configurations. Efforts will be made to determine the effect of the lead assembly configuration on frequency dependence. The drop in insulation resistance below 1 M $\Omega$ at high temperatures is disturbing. New insulators should be tested. An effort should be made to determine how much leakage is through the leads and how much is through the element support.

At this stage, we can really say little about the suitability of our tungsten thermometer. It seems to be approaching the stability of the birdcage thermometers and could surpass their stability. Certainly, further work is merited on the investigation of initial stabilization and coil configurations. 
It is clear from our results that several projects should be continued or started. Stability testing should continue with more frequent monitoring of the thermometers at low temperature fixed points. New insulator and element configuration combinations should be tested for stability and insulation resistance. Work should continue with tungsten and new materials for thermometer elements should be investigated. 


\section{References}

[1] Berry, R. J., The Influence of Crystal Defects in Platinum on Platinum Resistance Thermometry, Vol. 4, Temperature, Its measurement and Control in Science and Industry (Instrument Society of America, Pittsburgh, Pennsylvania, in press).

[2] Evans, J.P. and Burns, G. W., A Study of Stability of High Temperature Platinum Resistance Thermometers, Vol. 3, Part 1, 313, Temperature, Its Measurement and Control in Science and Industry (Reinhold Publishing Corporation, New York, 1962).

[3] Evans, J. P. and Wood, S. D., An Intercomparison of High Temperature Platinum Resistance Thermometers and Standard Thermocouples, Metrologia I, No. 3, 108 (July, 1971).

[4] Sawada, S. and Mochizuki, T., Stability of 25 Ohm Platinum Thermometer up to $1100{ }^{\circ} \mathrm{C}$, Vol. 4, Temperature, Its Measurement and Control in Science and Industry

(Instrument Society of America, Pittsburgh, Pennsylvania, in press).

[5] Anderson, R. I., The Stability of Platinum Resistance Thermometers, Vol. 4, Temperature, Its Measurement and Control in Seience and Industry (Instrument Society of America, Pittsburgh, Pennsylvania, in press).

[6] Hogben, D., Peavy, S. T., and Varner, R. N., OMNITAB II, User's Reference Manual, Nat1. Bur. Stand. (U.S.), Tech. Note 552, 264 pages (October, 1971).

[7] Curtis, D. J. and Thomas, G. J., Long Term Stability and Performance of Platinum Resistance Thermometers for Use to $1063^{\circ} \mathrm{C}$, Metrologia 4, No. 4, 184 (October, 1968).

[8] McLaren, E. H., and Murdock, E. G., Radiation Effects in Precision Resistance Thermometry: I Radiation Losses in Transparent Thermometer Sheaths, Can. J. Phys. 44,2631 (1966).

[9] Natrella, M. G., The Treatment of Outliers, Chapter 17, Natl. Bur. Stand. (U.S.), Handbook 91, 2nd edition (October, 1966). 


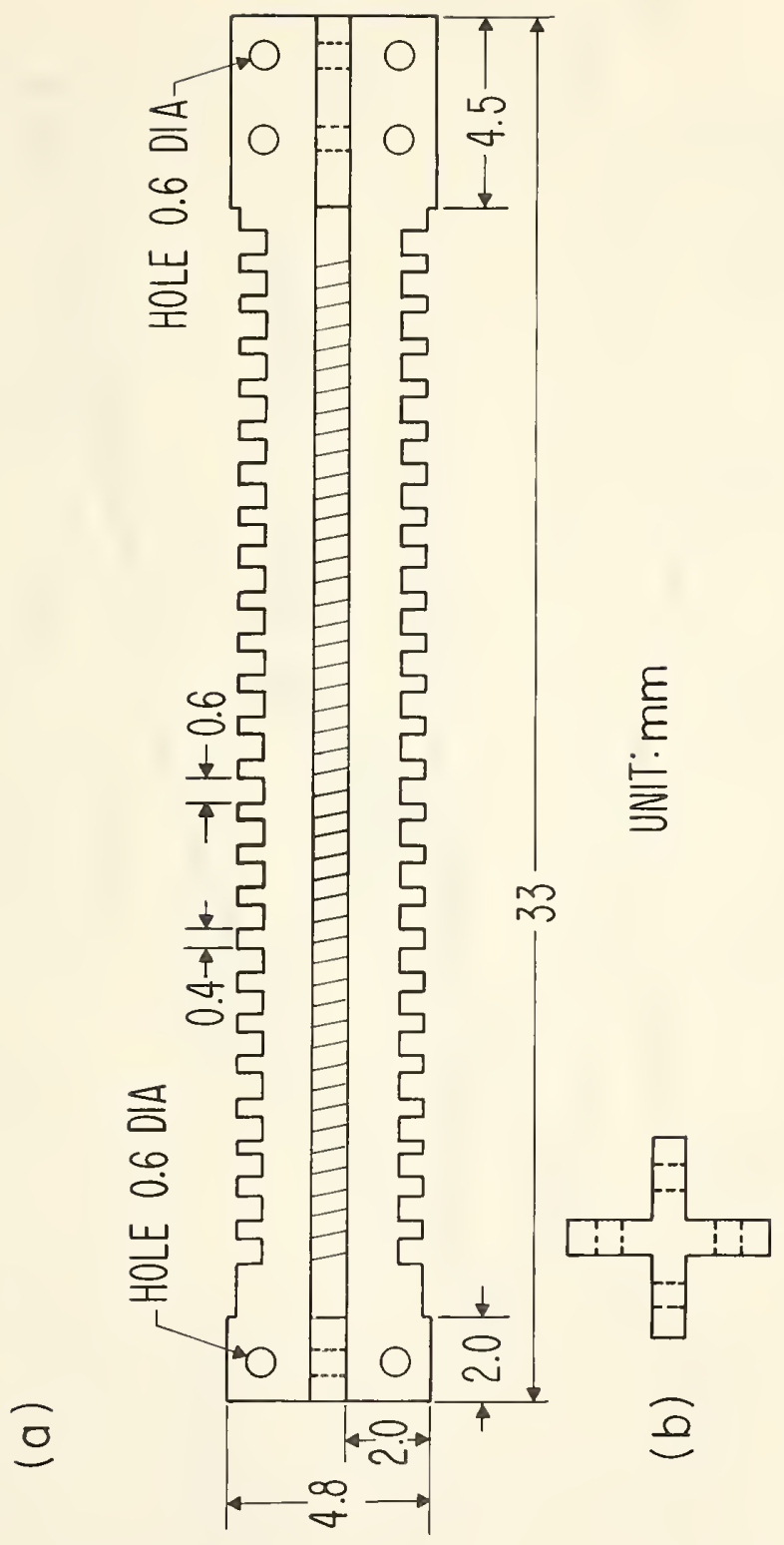




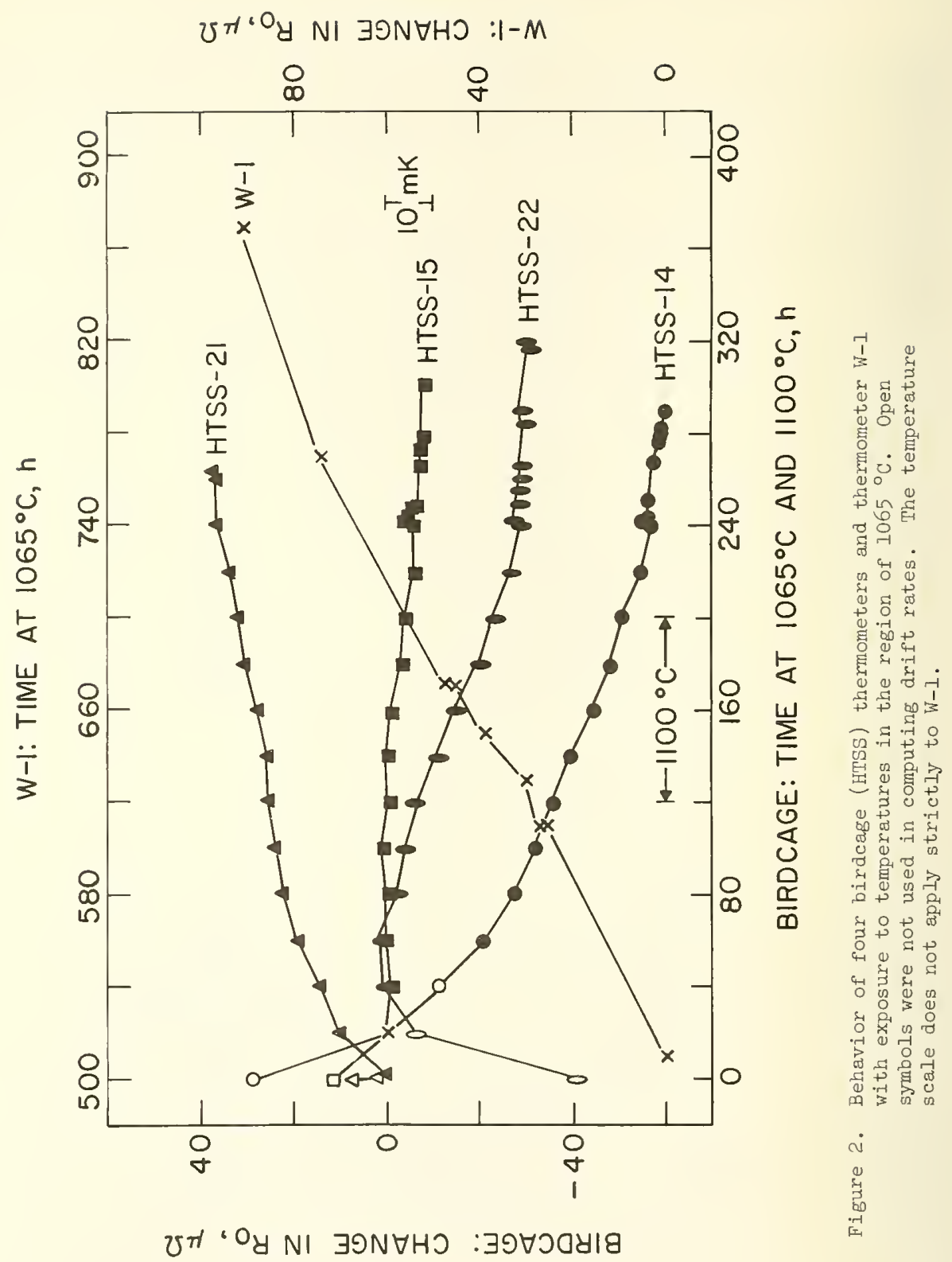




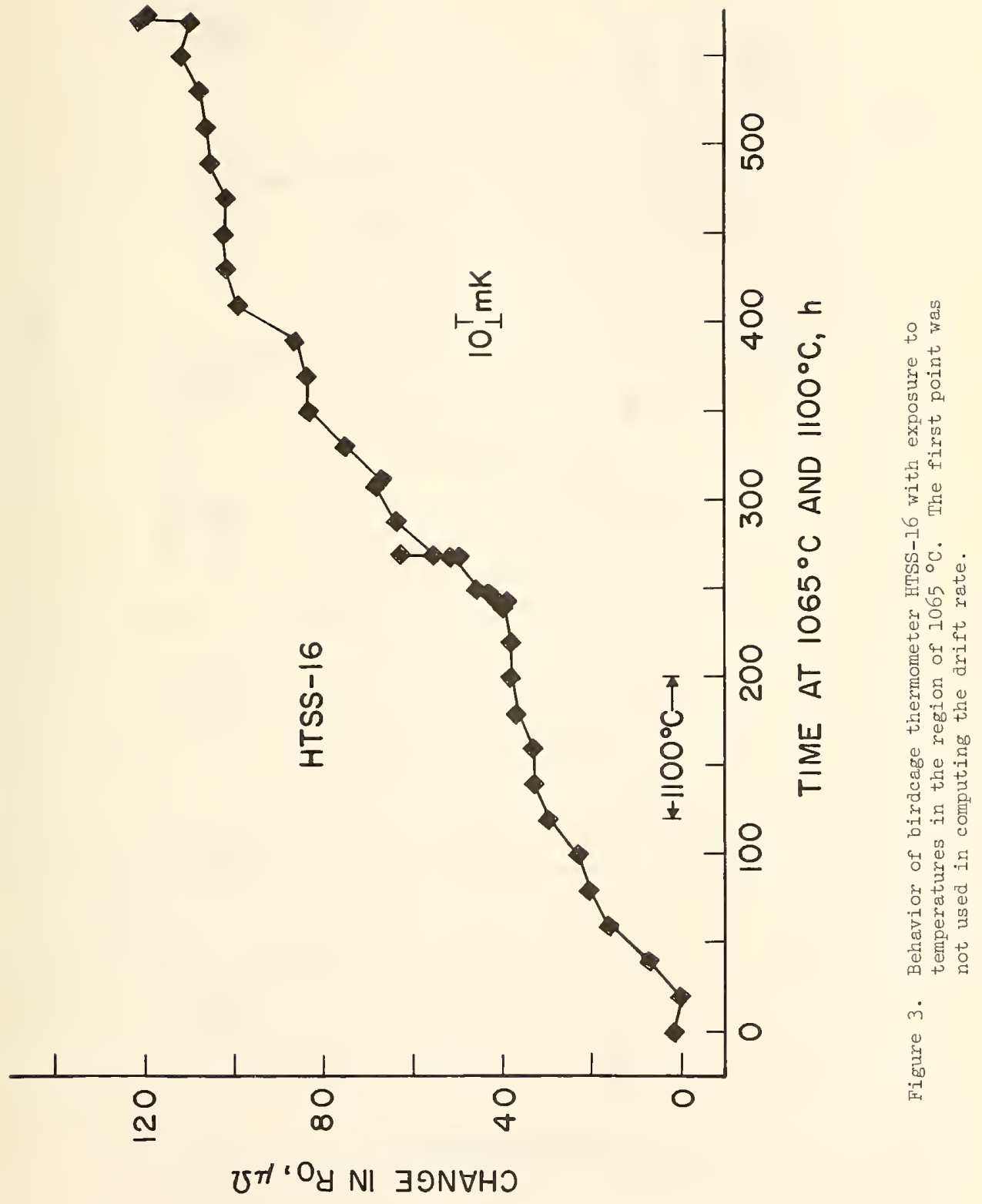



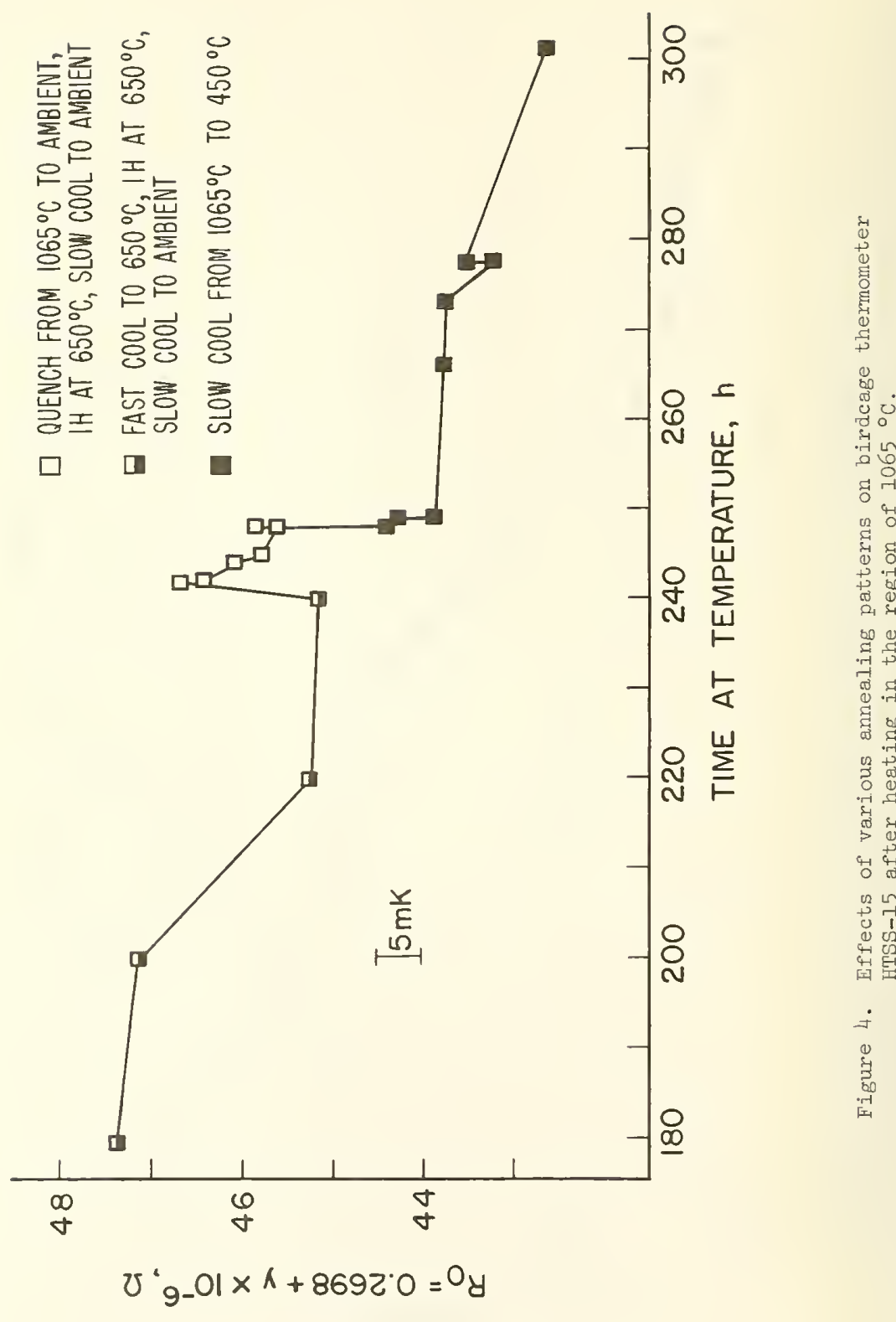


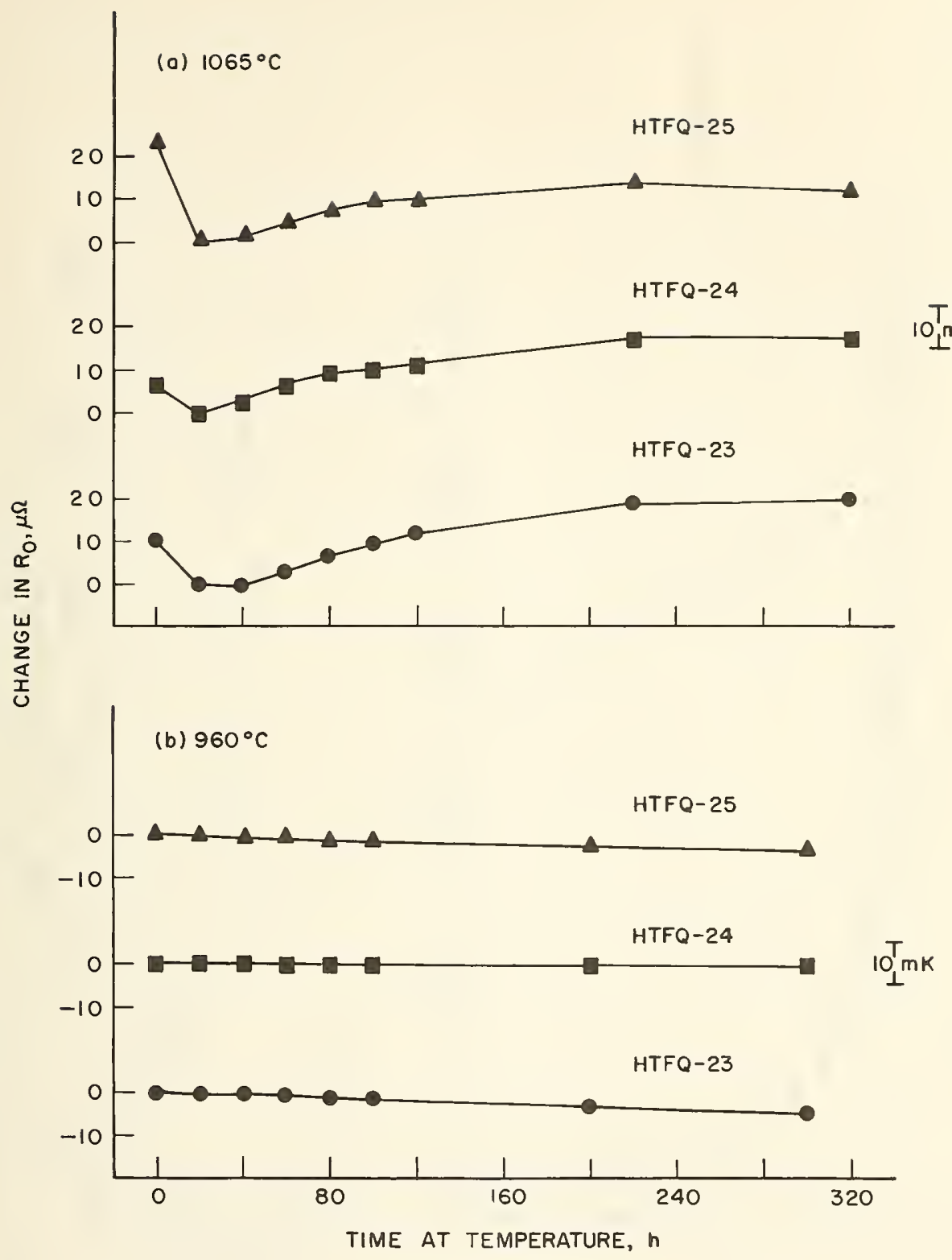

Figure 5. Behavior of cross (HTFQ) thermometers. (a) Exposed to $1065{ }^{\circ} \mathrm{C}$. The first point in each case was not used in computing the drift rate. (b) Exposed to $960{ }^{\circ} \mathrm{C}$. 


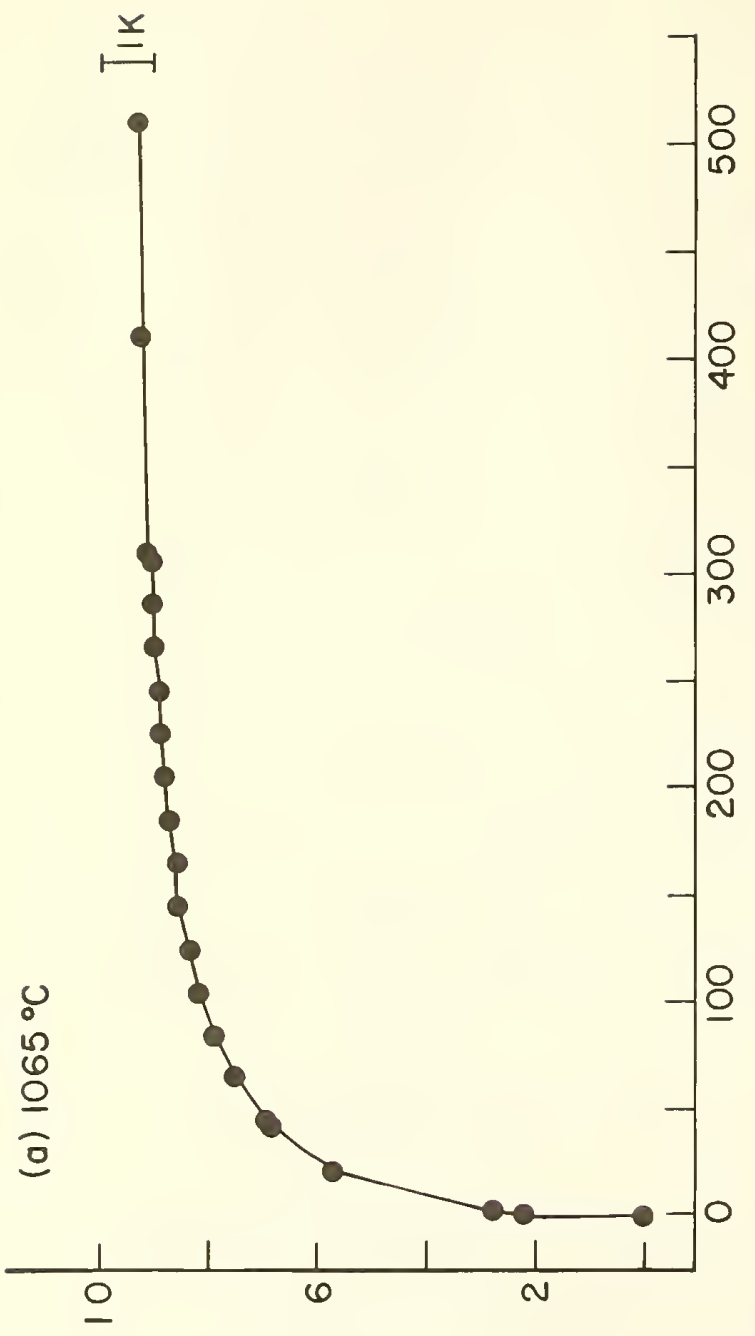

$\mho س \mathrm{O}^{\circ} \mathrm{NI} \exists 9 \mathrm{~N} \forall \mathrm{HO}$

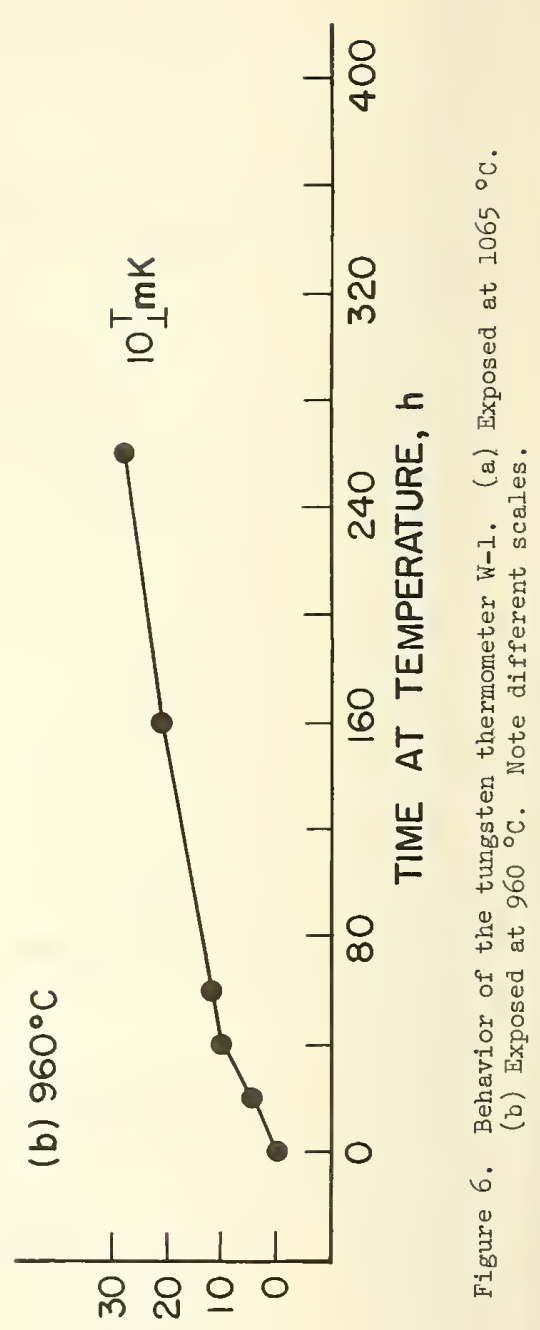

चत' $\mathrm{O}_{\mathrm{y}} \mathrm{NI} \exists 9 \mathrm{~N} \forall \mathrm{HO}$ 


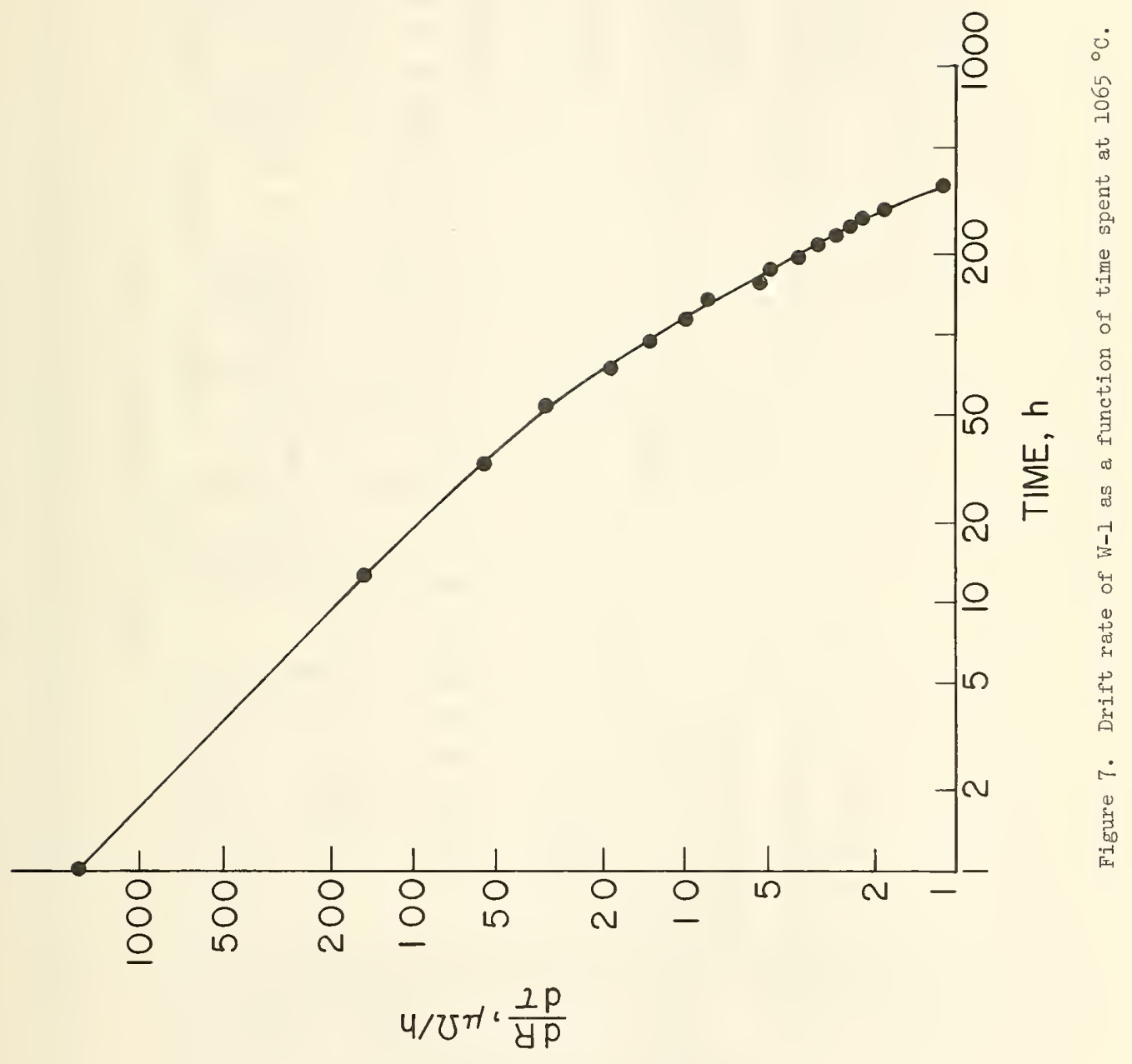




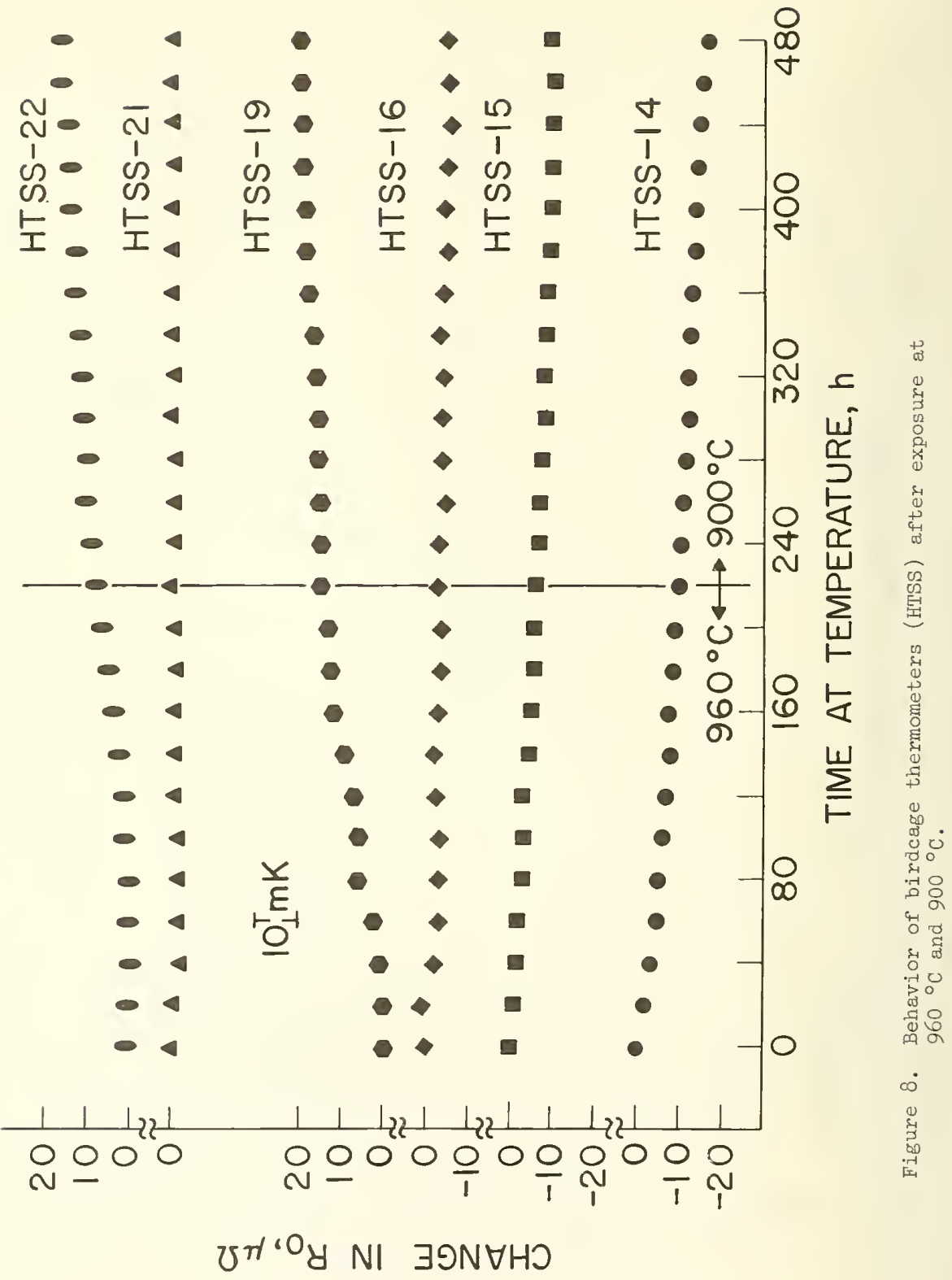




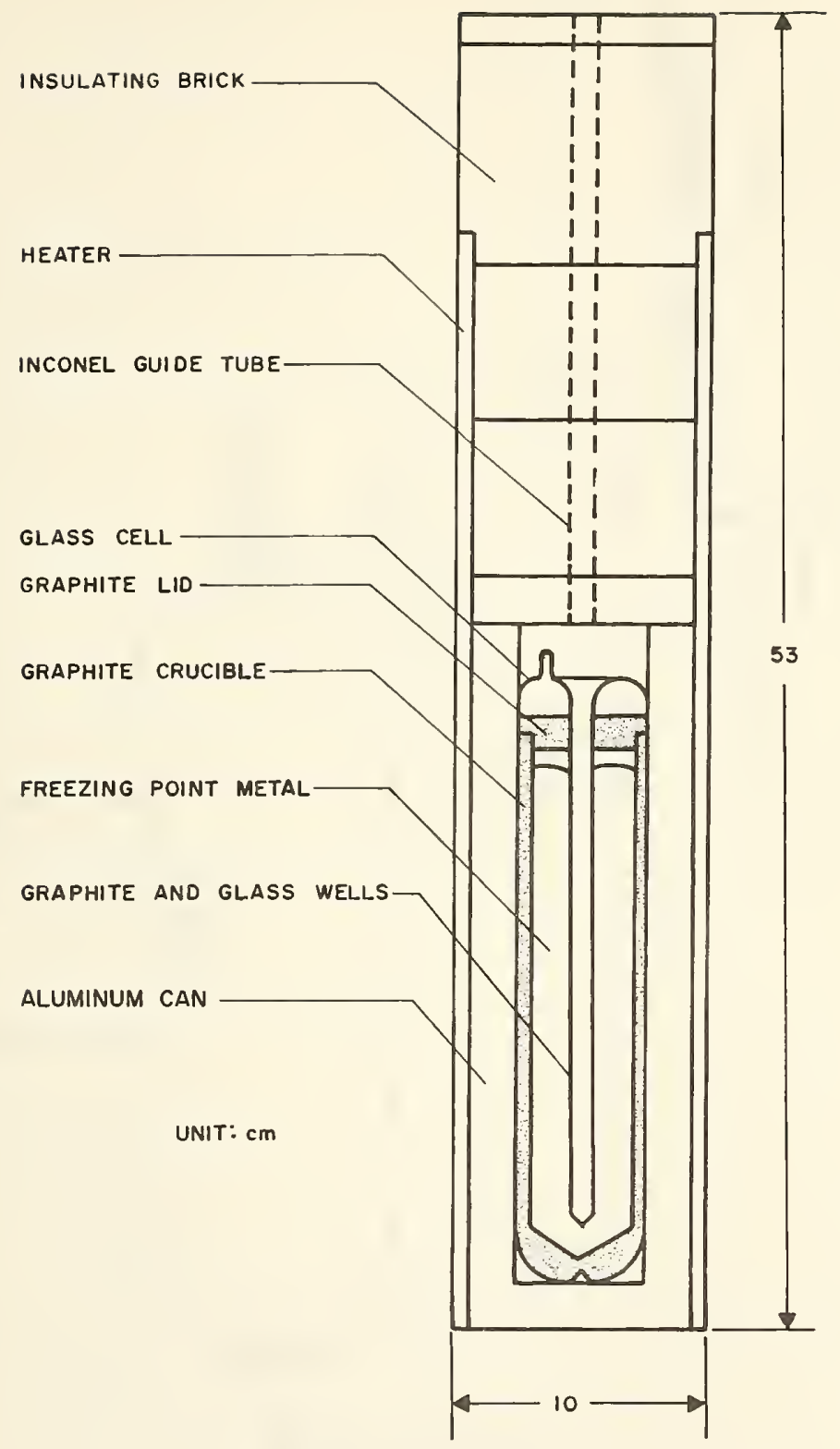

Figure 9. Details of the construction of the core of the low temperature furnace and of the hermetically sealed freezing-point-of-zinc cell. 


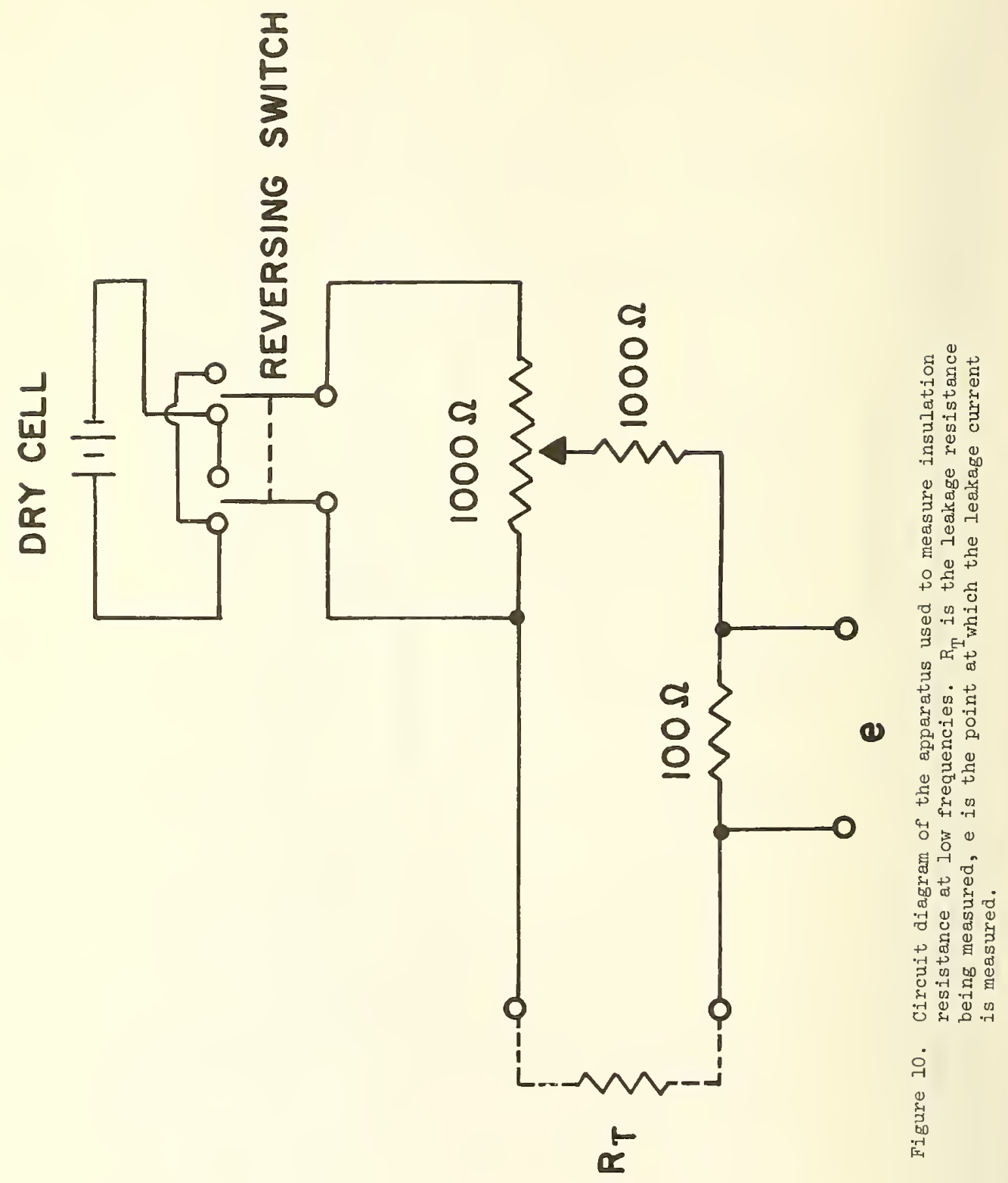




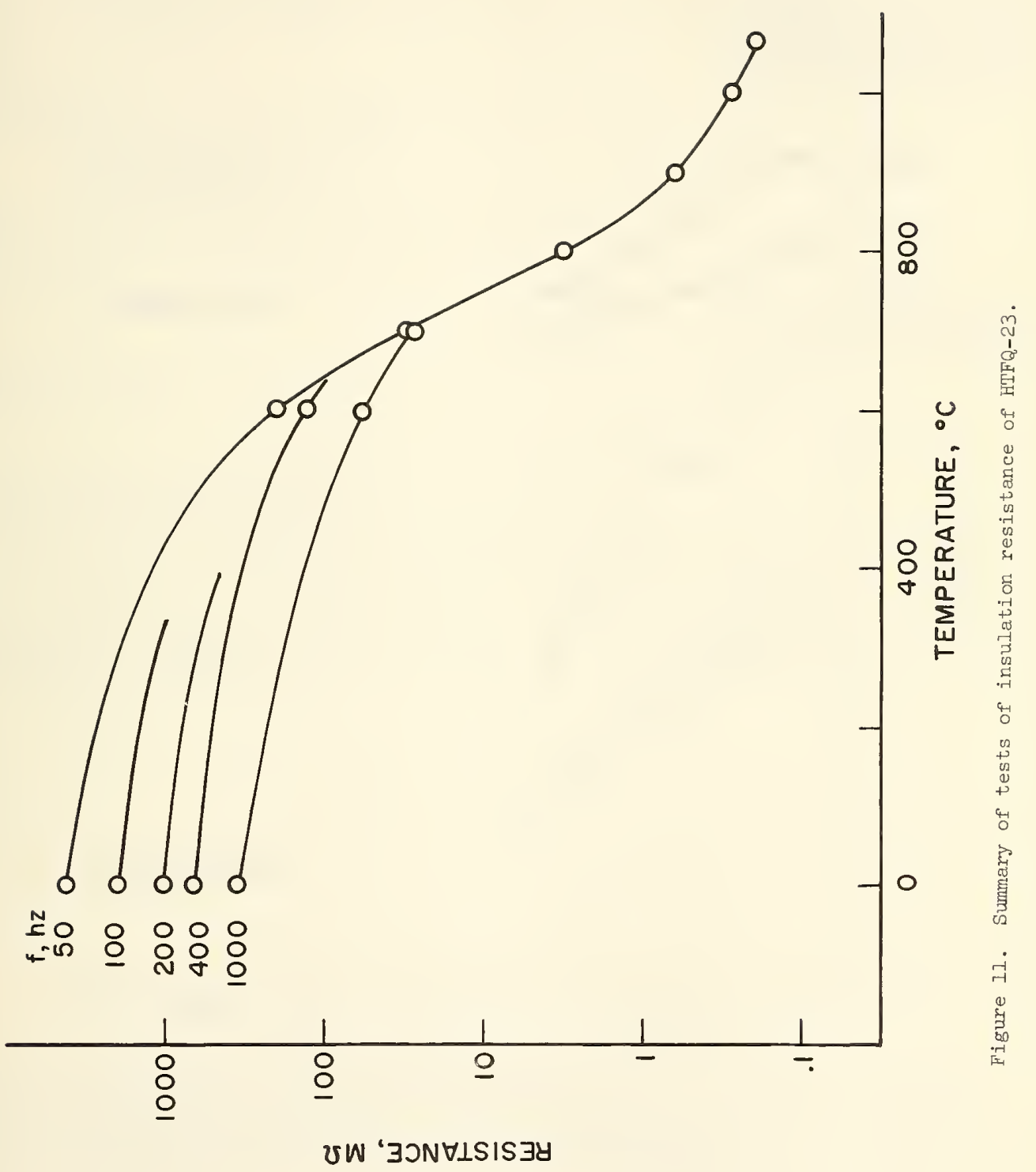




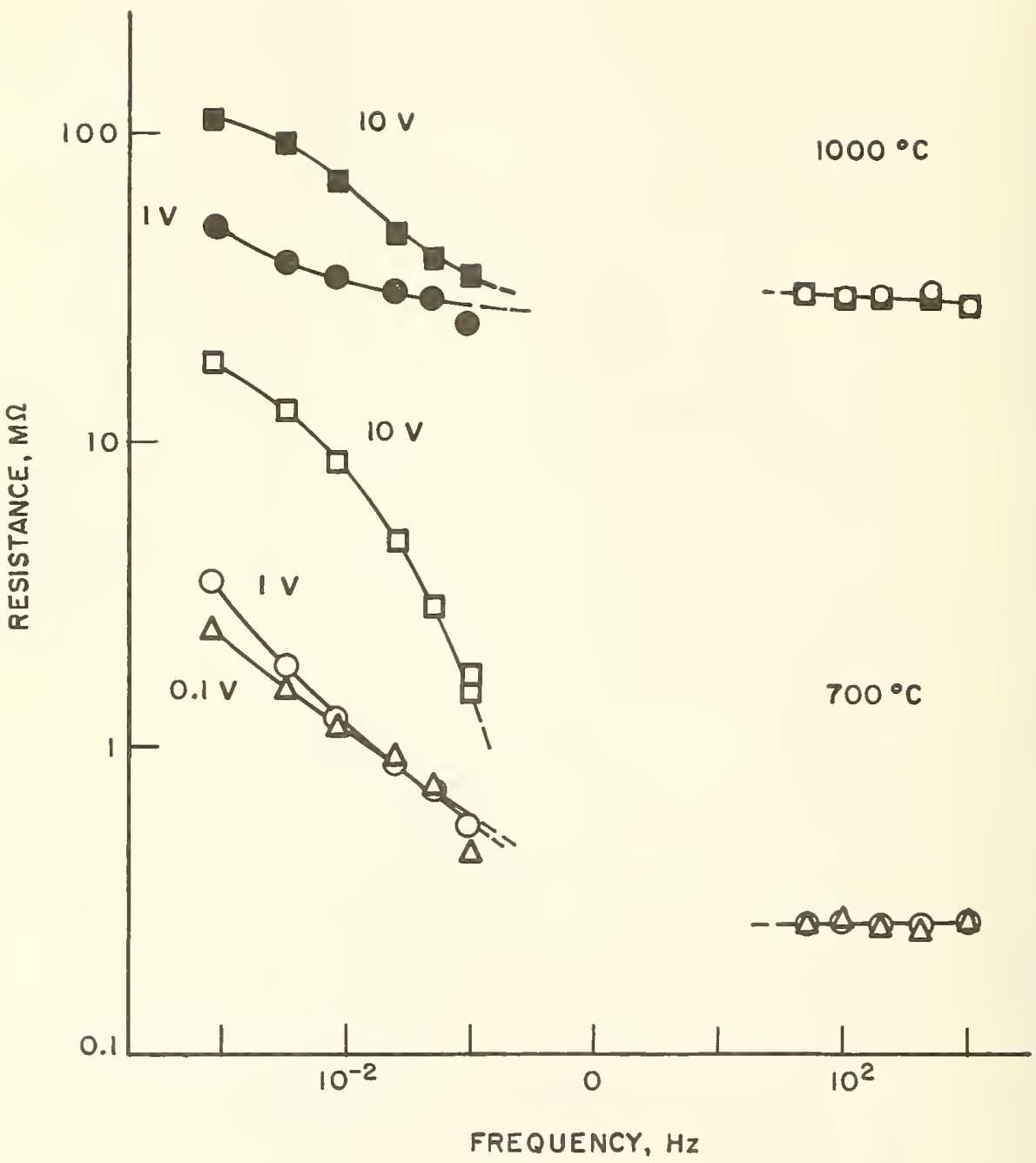

Figure 12. Typical sets of data for the insulation resistance of HTFQ-23 at two temperatures and several voltages. 
FORM NBS-114A (1-71)

\begin{tabular}{|c|c|c|c|}
\hline $\begin{array}{l}\text { U.S. DEPT. OF COMM. } \\
\text { BIBLIOGRAPHIC DATA } \\
\text { SHEET }\end{array}$ & $\begin{array}{l}\text { 1. PUBLICATION OR REPORT NO. } \\
\text { NBS TN }-764\end{array}$ & $\begin{array}{l}\text { 2. Gov't Accession } \\
\text { No. }\end{array}$ & 3. Recipient's Accession No. \\
\hline \multicolumn{3}{|c|}{$\begin{array}{l}\text { 4. TITLE AND SUBTITLE } \\
\text { An Investigation of the Stability of and Insulation Leakage } \\
\text { in Some High Temperature Resistance Thermometers: An Interim } \\
\text { Report. }\end{array}$} & \begin{tabular}{|l|} 
5. Publication Date \\
May 1973 \\
6. Performing Organization Code
\end{tabular} \\
\hline \multicolumn{3}{|c|}{ 7. AUTHOR(S) } & 8. Performing Organization \\
\hline \multicolumn{3}{|c|}{$\begin{array}{l}\text { 9. PERF ORMING ORGANIZATION NAME AND ADDRESS } \\
\text { NATIONAL BUREAU OF ST AND ARDS } \\
\text { DEPARTMENT OF COMMERCE } \\
\text { WASHINGTON, D.C. } 20234\end{array}$} & 10. Project/Task/Work Unit No. \\
\hline \multicolumn{3}{|c|}{$\begin{array}{l}\text { 12. Sponsoring Otganization Name and Address } \\
\text { Same as No. } 9\end{array}$} & $\begin{array}{l}\text { 13. Type of Report \& Period } \\
\text { Covered } \\
\text { Interim } \\
\text { Jan. I - Dec. 31, } 1972 \\
\text { 14. Sponsoring Agency Code }\end{array}$ \\
\hline
\end{tabular}

15. SUPPLEMENT ARY NOTES

16. ABSTRACT (A 200-word or less factual summary of most significant information. If document includes a significant bibliography or literature survey, mention it here.)

Data are presented concerning the stability of high temperature resistance thermometer Two types of platinum and one type of tungsten thermometer were tested at $1065^{\circ} \mathrm{C}$ and $960{ }^{\circ} \mathrm{C}$. Some of the platinum thermometers were also tested at $900{ }^{\circ} \mathrm{C}$ and at the freezing point of zinc. Results of tests are also given on the insulation resistance of sensor supports and lead assemblies for the two types of platinum thermometers. A new design for a zinc-point cell is discussed briefly. Suggestions for future work are indicated.

17. KEY WORDS (Alphabetical order, separated by semicolons) Freezing point of zinc; high temperature resistance thermometer; insulation resistance; platinum resistance thermometer; resistance thermometer; stability; tungsten thermometer; zine.

18. AVAILABILITY STATEMENT

X UNL IMITED.

FOR OFFICIAL DISTRIBUTION. DO NOT RELEASE TO NTIS. 19. SECURITY CLASS
(THIS REPORT)

UNCL ASSIF IED

20. SECURITY CLASS (THIS PAGE)

UNCL ASSIFIED
21. NO. OF PAGES 31

22. Price

$\$ .50$ Domestic Postpaid \$.35 GPO Bookstore 

PERIOOICALS

JOURNAL OF RESEARCH reports National Bureau of Standards research and development in physics, mathematics, and chemistry. Comprehensive scientific papers give complete details of the work, including laboratory data, experimental procedures, and theoretical and mathematical analyses. Illustrated with photographs, drawings, and charts. Includes listings of other NBS papers as issued.

Published in two sections, available separately:

\section{- Physics and Chemistry (Section A)}

Papers of interest primarily to scientists working in these fields. This section covers a broad range of physical and chemical research, with major emphasis on standards of physical measurement, fundamental constants, and properties of matter. Issued six times a year. Annual subscription: Domestic, $\$ 17.00$; Foreign, \$21.25.

\section{- Mathematical Sciences (Section B)}

Studies and compilations designed mainly for the mathematician and theoretical physicist. Topics in mathematical statistics, theory of experiment design, numerical analysis, theoretical physics and chemistry, logical design and programming of computers and computer systems. Short numerical tables. Issued quarterly. Annual subscription: Domestic, $\$ 9.00$; Foreign, $\$ 11.25$.

\section{TECHNICAL NEWS BULLETIN}

The best single source of information concerning the Bureau's measurement, research, developmental, cooperative, and publication activities, this monthly publication is designed for the industry-oriented individual whose daily work involves intimate contact with science and technology-for engineers, chemists, physicists, research managers, product-development managers, and company executives. Includes listing of all NBS papers as issued. Annual subscription: Domestic, $\$ 6.50$; Foreign, $\$ 8.25$.

\section{NONPERIODICALS}

Applied Mathematics Series. Mathematical tables, manuals, and studies.

Building Science Series. Research results, test methods, and performance criteria of building materials, components, systems, and structures.

Handbooks. Recommended codes of engineering and industrial practice (including safety codes) developed in cooperation with interested industries, professional organizations, and regulatory bodies.

Special Publications. Proceedings of NBS conferences, bibliographies, annual reports, wall charts, pamphlets, etc.

Monographs. Major contributions to the technical literature on various subjects related to the Bureau's scientific and technical activities.

\section{National Standard Reference Data Series.} NSRDS provides quantitative data on the physical and chemical properties of materials, compiled from the world's literature and critically evaluated.

Product Standards. Provide requirements for sizes, types, quality, and methods for testing various industrial products. These standards are developed cooperatively with interested Government and industry groups and provide the basis for common understanding of product characteristics for both buyers and sellers. Their use is voluntary.

Technical Notes. This series consists of communications and reports (covering both other-agency and NBS-sponsored work) of limited or transitory interest.

Federal Information Processing Standards Publications. This series is the official publication within the Federal Government for information on standards adopted and promulgated under the Public Law 89-306, and Bureau of the Budget Circular A-86 entitled, Standardization of Data Elements and Codes in Data Systems.

Consumer Information Series. Practical information, based on NBS research and experience, covering areas of interest to the consumer. Easily understandable language and illustrations provide useful background knowledge for shopping in today's technological marketplace.

\section{BIBLIOGRAPHIC SUBSCRIPTION SERVICES}

The following current-awareness and literature-survey bibliographies are issued periodically by the Bureau:

CEyogenic Data Center Current Awareness Service (Publications and Reports of Interest in Cryogenics). A. literature survey issued weekly. Annual subscription: Domestic, $\$ 20.00$; foreign, $\$ 25.00$.

I.ı̨iquefied Natural Gas. A literature survey issued quarterly. Annual subscription: $\$ 20.00$.

Superconducting Devices and Materials. A literature survey issued quarterly. Annual subscription: $\$ 20.00$. Send subscription orders and remittances for the preceding bibliographic services to the U.S. Department of Commerce, National Technical Information Service, Springfield, Va. 22151.

Flectromagnetic Metrology Current Awareness Service (Abstracts of Selected Articles on Measurement Techniques and Standards of Electromagnetic Quantities from D-C to Millimeter-Wave Frequencies). Issued monthly. Annual subscription: $\$ 100.00$ (Special rates for multi-subscriptions). Send subscription order and remittance to the Electromagnetic Metrology Information Center, Electromagnetics Division, National Bureau of Standards, Boulder, Colo. 80302.

Order NBS publications (except Bibliographic Subscription Services) from: Superintendent of Documents, Government Printing Office, Washington, D.C. 20402. 
U.5. DEPARTMENT OF COMMERCE

National Bureau of Standards

Washington, D.C. 20234

OFFICIAL BUSINESS

Penalty for Private Use, $\$ 300$
POSTAGE AND FEES PAID U.S. DEPARTMENT OF COMMERCE 215

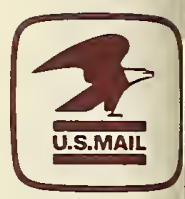

